\author{
Marzena Barańska', Lucyna Szot² \\ ${ }^{1}$ Uniwersytet Jagielloński w Krakowie, ${ }^{2}$ Uniwersytet Wrocławski
}

\title{
Etyka w reklamie a granice wypowiedzi (kontekst samoregulacji)
}

\section{Ethics in advertising and the limits of expression (self-regulation context)}

\begin{abstract}
ABSTRAKT
Celem artykułu jest omówienie wpływu etyki na kształtowanie rynku reklamy, zarówno w kontekście wpływu na treść przekazu, zachodzących procesów samoregulacyjnych, ewolucji środowiska marketingowego, jak i wzrostu aktywności społeczeństwa w procesie przestrzegania wartości społecznie cenionych. W obliczu ograniczonej skuteczności egzekucji prawa, powodowanej zmianami technologicznymi na rynku medialnym, rośnie rola i znaczenie rozwiązań pozanormatywnych. Przyjęto hipotezę, że środowisko reklamodawców i dostawców treści medialnych hołduje zasadzie społecznej odpowiedzialności biznesu, czego wyrazem są stanowione rozwiązania pozanormatywne oraz skuteczność ich egzekucji przez uprawnione organy. Procesy profesjonalizacji i instytucjonalizacji zachodzące na forum międzynarodowym, zobowiązują do rozważenia kwestii dotyczących normatywnego ujęcia etyki i formalnych podstaw wydawania rozstrzygnięć przez powołane do tego organy.

Dyskredytowanie reklam kwalifikowanych jako nieetyczne, jest nie tylko wyrazem wzrostu świadomości społecznej (opinia publiczna za pośrednictwem dostępnych kanałów komunikacji i narzędzi wyraża swoje niezadowolenie), ale także wyrazem
\end{abstract}

skutecznej kontroli. Publikacja nawiązuje do dyskursu społecznego w przedmiocie roli, jaką pełni w społecznej teorii komunikacji J. Habermasa, koncepcja Media Accountability Systems (MAS) autorstwa Claude Jean Bertrand'sa i teorii neoinstytucjonalnej (M. Weber, J. Powell i DiMaggio). Przyjęte założenie wpisuje się w nurt zagadnień dotyczących zarządzania organizacją medialną, zawartością treści przekazu reklamowego, a zatem m.in. nauk: o mediach i komunikacji społecznej, ekonomii w zakresie marketingu (zawartości przekazu). Za podstawowe uznano pytania: W jakim stopniu samoregulacja oddziałuje na treść emitowanych reklam? W jakim stopniu ograny nadzorujące sferę etyki reklamy kształtują nową rzeczywistości i jakie czynniki determinują ich działania? Udzielenie odpowiedzi na powyższe pytania wymagało zastosowania metody egzegezy tekstów prawnych, metody komparatystycznej (analiza podobieństw i odmienności istotnych aspektów prawa reklamy UE i Polski), metody instytucjonalnej (analiza przebiegu wdrażania zmian instytucjonalnych oraz próba oceny skuteczności ich realizacji) oraz analizy zawartości treści przekazów reklamowych. Pomocną w przygotowaniu publikacji okazała się analiza uchwał i decyzji wydanych przez Radę Etyki Reklamy. 
SŁOWA KLUCZOWE:

etyka, samoregulacja, reklama, kodeksy etyczne, odpowiedzialność prawna

ABSTRACT

The aim of the article is to discuss the impact of ethics on the shaping of the advertising market, both in the context of influence on the content of the message, self-regulatory processes taking place, the evolution of the marketing environment, as well as the increase in the activity of society in the process of observing socially valued values. In the face of limited effectiveness of law enforcement, caused by technological changes in the media market, the role and importance of non-standard solutions is growing. It has been hypothesised that the environment of advertisers and media content providers adheres to the principle of corporate social responsibility, which is reflected in non-normative solutions and their effective enforcement by authorised bodies. The processes of professionalisation and institutionalisation taking place in the international forums oblige to consider the issues related to the normative understanding of ethics and the formal basis for issuing decisions by the bodies appointed to that end.

Discrediting of advertisements qualified as unethical is not only an expression of growth of social awareness which (public opinion through available communication channels and tools expresses its dissatisfaction), but also an expression of effective control. The publication refers to the social discourse on the role played in J. Habermas' social theory of communication, Claude Jean Bertrand's concept of Media Accountability Systems (MAS) and neo-institutional theory (M. Weber, J. Powell and DiMaggio). The adopted assumption is part of the stream of issues concerning the management of media organisation, the content of the advertising message, thus, among others, the sciences of: the media and social communication, economics in the field of marketing (message content). The questions considered to be fundamental were: To what extent does self-regulation influence the content of broadcast advertising? To what extent do the bodies supervising the sphere of advertising ethics shape the new reality and what factors determine their actions? To answer these questions it was necessary to use the method of exegesis of legal texts, the comparative method (analysis of similarities and dissimilarities of important aspects of the EU and Polish advertising law), the institutional method (analysis of the course of implementation of institutional changes and an attempt to assess the effectiveness of their implementation) and content analysis of advertising messages. Analysis of resolutions and decisions issued by the Council of Ethics in Advertising proved helpful in preparation of the publication.

\section{KEYWORDS:}

ethics, self-regulation, advertising, codes of ethics, legal responsibility.

\section{WSTĘP}

Najczęściej każdy ma świadomość, co jest etyczne, a co jest sprzeczne z powszechnie przyjętymi zasadami. Wyznaczanie granic, w ujęciu pozanormatywnym nacechowane jest indywidualnym podejściem jednostki, wynikającym m.in. z preferowanego systemu wartości, interkulturowości czy światopoglądu. Mimo 
wyznaczonej płaszczyzny dozwolonych praktyk, sfera etyki z uwagi na różnorodność pojmowania niektórych terminów, budzi wiele kontrowersji. To, co czasami przez jednych uznawane jest za społecznie cenione, dla innych jest wysoce naganne. Nie ulega jednak wątpliwości, że wieloletnie doświadczenia wynikające ze stosowania mechanizmów oddziaływania na procesy decyzje konsumentów nie pozostały bez wpływu na postrzeganie reklamy, jako narzędzia działań marketingowych i stosowanych mechanizmów oddziaływania na ich procesy decyzyjne.

Etykę pojmować należy zarówno jako czynnik determinujący relacje pomiędzy podmiotami (jednostkami, organizacjami) (W. Gasparski, R. Sroka), jako następstwo kultury i/lub preferowanych wartości społecznie cenionych (ujęcie aksjologiczne). W sferze gospodarczej jest istotnym kryterium jakości zarządzania organizacją (A. Piekarczyk). W kontekście funkcjonowania mediów etykę postrzegać należy przede wszystkim jako ogół zasad kreujących relacje pomiędzy podmiotami, ich odbiorcami, pracownikami, w tym także dotyczących działalności reklamowej. Terminem moralność można określić jako osobistą etykę oraz poczucie obowiązku każdej jednostki, ufundowane na jej światopoglądzie i życiowym doświadczeniu. Według niektórych badaczy, zasady tak pojętej moralności to jedyne ograniczenie, jakie można nałożyć na wolność wypowiedzi.

W odniesieniu do reklamy, istotne znaczenie ma etyczne zarządzanie treścią przekazu, albowiem nieakceptowane treści coraz częściej są krytycznie oceniane, nie tylko przez uprawnione instytucje, ale adresatów przekazów, zwłaszcza reklamowych - potencjalnych konsumentów. Siła oddziaływania tych ostatnich, odzwierciedlona jest m.in. dezaprobatą i niezadowoleniem społecznym czy bojkotem zakupu towarów. Inną formą społecznej dezakceptacji dla dystrybuowanych treści są m.in. upowszechniane, zwłaszcza w mediach społecznościowych krytyczne opinie, ale również potrzeba prowadzenia działań oddolnych związana z organizowaniem protestów, publicznych wystąpień.

To, co postrzegane było jako czynnik uzupełniający - etyczny wymiar reklam - zyskuje coraz większe znaczenie. Zarówno reklamodawcy jak i dostawcy reklam przywiązują wagę do podejmowania działań „(...) nie wzbudzających negatywnych emocji związanych z naruszeniem wyznawanych przez odbiorców zasad etycznych i światopoglądowych"1. Wagę etycznych rozwiązań potwierdza

${ }^{1}$ R. Nowacki, Postawy Polaków wobec nieetycznych działań reklamowych $w$ świetle funkcjonowania Kodeksu Etyki Reklamy, „Handel Wewnętrzny” 2016, nr 1, s. 290-303. 
aktualnie obowiązujące prawo, ${ }^{2}$ reglamentujące rynek medialny i stanowiące asumpt do analizy etyki w ujęciu normatywnym.

Osobną kategorią jest deontologia, której zasady (czasem zredagowane w kartach zasad i obowiązków) są stosowane w ramach danej profesji. Często chodzi o niepisaną tradycję, która określa to „co wolno a czego nie”. Deontologia oznacza zbiór zasad i reguł ustanowionych przez środowisko medialne i marketingowe (najlepiej we współpracy z reklamodawcami). Deontologia nie stanowi prawa ani nawet - w ścisłym znaczeniu - zasad etycznych. Ma na celu skuteczniejsze wychodzenie naprzeciw potrzebom poszczególnych grup odbiorców. Także reklamodawcom zależy na wiarygodności środka przekazu, w którym wykupują czas antenowy. Zatem zauważalna jest rosnąca troska przedsiębiorców (reklamodawców) o skutki, jakie wywołują wprowadzone przez nich na rynek produkty, oraz przekonanie, że wysoka jakość i standardy etyczne popłacają.

\section{Deontologia nie stanowi prawa ani nawet - w ścisłym znaczeniu - zasad etycznych. Ma na celu skuteczniejsze wychodzenie naprzeciw potrzebom poszczególnych grup odbiorców.}

Sygnalizowane podejście wpływa także na wzrost znaczenia organizacji nadzorujących przestrzeganie kodeksów etycznych. Podkreślić należy, że nie liczba tworzonych dokumentów, ale skuteczność wdrażanych rozwiązań i egzekucji, przesądza o ich atrakcyjności. Dojrzałość sygnatariuszy kart, porozumień, kodeksów etycznych jest istotnym czynnikiem determinującym praktyczny wymiar stanowionych rozwiązań i skuteczności ich egzekwowania. Zaobserwowana zmienność podejść w zakresie postrzegania roli etyki w zarządzaniu treścią przekazu, ewolucja wartości preferowanych przez decydentów w mediach i po stronie

${ }^{2}$ Dyrektywa Parlamentu Europejskiego i Rady (UE) 2018/1808 z dnia 14 listopada 2018 r. zmieniająca dyrektywę 2010/13/UE w sprawie koordynacji niektórych przepisów ustawowych, wykonawczych i administracyjnych państw członkowskich dotyczących świadczenia audiowizualnych usług medialnych (dyrektywa o audiowizualnych usługach medialnych) ze względu na zmianę sytuacji na rynku, PE/33/2018/REV/1, OJ L 303, 28.11.2018, p. 69-92. 
reklamodawców, wymagają permanentnej analizy. Wiele z publikacji podejmuje kwestie dotyczące kwalifikowania reklam jako kontrowersyjnych (E. Lasek, A. Strażowian, M. Jacewicz), inne wskazują na determinanty perswazyjnego przekazu (E. Liput, A. Ozimek). Niniejsza publikacja wychodzi poza zakres prowadzonych dotychczas analiz, łącząc elementy samoregulacji, stosowanych rozwiązań deontologicznych, z praktycznym wymiarem ich zastosowań - w oparciu o analizę wybranych przykładów.

Złożoność zagadnienia stała się przyczynkiem do omówienia tematu związanego z wpływem etyki na wyznaczanie granic wypowiedzi reklamowej. Z uwagi na powyższe przyjęto następującą hipotezę: zachodzące procesy samokontroli środowiska reklamodawców odzwierciedlone w przyjętych rozwiązaniach pozanormatywnych, wpisują się w katalog założeń związanych ze społeczną odpowiedzialnością biznesu, ale przede wszystkim wyznaczają granice wolności wypowiedzi gospodarczej sankcjonowane m.in. dobrymi obyczajami i deontologią zawodową. Tak opisany problem badawczy wymagał zastosowania imperatywu funkcjonalnego. $\mathrm{Z}$ tego względu za podstawowe uznano pytanie badawcze: $\mathrm{W}$ jakim stopniu samoregulacja oddziałuje na treść emitowanych reklam? Udzielenie odpowiedzi wymagało zarówno analizy teoretycznej pojęć podstawowych, jak i oceny działalności funkcjonujących w Polsce organizacji oraz skuteczności wydanych rozstrzygnięć. $\mathrm{Z}$ tego względu uzasadnione było zastosowanie metody: egzegezy tekstów prawnych, metody komparatystycznej (analiza podobieństw i odmienności istotnych aspektów prawa reklamy UE i Polski), metody instytucjonalnej (analiza przebiegu wdrażania zmian instytucjonalnych oraz próba oceny skuteczności ich realizacji) oraz analizy zawartości treści przekazów reklamowych. Pomocną w przygotowaniu publikacji okazała się analiza uchwał i decyzji wydanych przez Radę Etyki Reklamy.

\section{UWARUNKOWANIA I POJĘCIE SAMOREGULACJI}

O skuteczności stanowionego iuris przesądza poziom egzekwowania przyjętych praw. Pojęcie kompletności uległo modyfikacji na przestrzeni lat i można stwierdzić, że zakresem swym obejmuje środki regulacyjne, jak i nieregulacyjne. 0 ile pierwsze to katalog rozwiązań normatywnych, drugie to przyjęte i powszechnie aprobowane rozwiązania etyczne przyjęte $\mathrm{w}$ formie deontologii zawodowej czy kart, kodeksów etycznych. 
Najczęściej termin reglamentacja kojarzy się z normatywnym zakresem dozwolonych działań, stanowionymi nakazami i zakazami. Odrębny obszar, stanowi sfera tego, co poza prawem jest respektowane lub oceniane, bądź oceniane jako naganne czy niedozwolone. Każdy człowiek oceniając zdarzenie, zachowania, wypowiedzi weryfikuje ich zawartość kierując się systemem wartości, tym co wyznaje, do czego jest przekonany, stanowiąc tym samym osobliwe granice dopuszczalnych zachowań. Indywidualne oceny stanowić mogą źródło dla akceptowanych zachowań przez grupy, społeczeństwa, co nie oznacza, że indywidualne oceny stanowią sumę tego, co jest preferowane przez dane społeczeństwo. Generalnie zasady tak pojętej moralności to jedyne ograniczenie, jakie można nałożyć na wolność wypowiedzi.

\section{Procesy samoregulacyjne wpisują się w powszechnie aprobowaną formułę społecznej odpowiedzialności biznesu i mają m.in. wzmocnić zaufanie do biznesu oraz do systemów norm i wartości społecznie cenionych.}

Procesy samoregulacyjne wpisują się $\mathrm{w}$ powszechnie aprobowaną formułę społecznej odpowiedzialności biznesu i mają m.in. wzmocnić zaufanie do biznesu oraz do systemów norm i wartości społecznie cenionych. Zaangażowanie jednostek, grup w stanowienie reglamentacji dla oznaczenia dozwolonej płaszczyzny działania, określane jest mianem samoregulacyjnych (self regulation). Termin samoregulacja interpretowany jest, jako działania podejmowane przez podmioty reprezentujące dane środowisko, hołdujące wartościom, zasadom, które stanowią podstawę dla kształtowania pozanormatywnych rozwiązań, zobowiązujących do ich przestrzegania przede wszystkim członków danej grupy, jak i podmioty zewnętrzne. W ujęciu normatywnym przyjęto, że „(...) podmioty gospodarcze przyjmują pewne zasady postępowania między sobą lub w stosunku do stron trzecich na rynku oraz w społeczeństwie i uzgadniają ich przestrzeganie między sobą, bez żadnych 
zewnętrznych mechanizmów przymusu” . „W swojej „czystej wersji” samoregulacja nie zakłada interwencji ze strony państwowych instytucji, gdyż inicjatywa ma charakter oddolny (buttom up)"4. Ograniczając interwencjonizm państwowy - w kontekście zakresu katalogowania zwyczajów, dobrych obyczajów, deontologii zawodowej czy treści kodeksów etycznych uzasadnianych dobrowolnością porządkowania reguł zarządzających daną sferą - gwarantują szybkość i skuteczność egzekwowania prawa, przez powołaną w tym zakresie strukturę instytucjonalnych rozwiązań.

Samoograniczanie stało się nie tylko modne, ale stanowi skuteczne narzędzie podejmowanych działań na rzecz eliminowania zachowań czy treści, co najmniej nie akceptowanych przez dane środowisko. „Na podstawie dostępnej literatury i przyjętych dokumentów, samoregulację można określić jako oddolne i całkowicie dobrowolne samozdyscyplinowanie się podmiotów prowadzących działalność w określonej branży, poprzez przyjęcie pewnych reguł postępowania oraz utworzenie systemu zapewniającego ich przestrzeganie. Istotą samoregulacji jest więc występowanie dwóch niezbędnych elementów: dobrowolności oraz samokontroli, natomiast warunkiem prawidłowego jej funkcjonowania jest odpowiedni poziom powszechności stosowania przyjętych samoograniczeń oraz realna możliwość ich egzekwowania"5. Oddolnie wprowadzane rozwiązania są także wyrazem dojrzałości środowiska i refleksji w odpowiedzi na potrzeby społeczne. W ten sposób samoregulacja utożsamiana jest ze „(...) świadomym, zaplanowanym strategicznie etycznym działaniem organizacji/firmy na rynku, której zachowania i standardy moralne wykraczają poza prawne zobowiązania oraz wiążą się z finansową oraz organizacyjną inwestycją w praktykę etyczną"6.

${ }^{3}$ Pkt. 3.2 Dyrektywa Parlamentu Europejskiego i Rady (UE) 2018/1808 z dnia 14 listopada 2018 r. zmieniająca dyrektywę 2010/13/UE w sprawie koordynacji niektórych przepisów ustawowych, wykonawczych i administracyjnych państw członkowskich dotyczących świadczenia audiowizualnych usług medialnych (dyrektywa o audiowizualnych usługach medialnych) ze względu na zmianę sytuacji na rynku, PE/33/2018/REV/1, OJ L 303, 28.11.2018, p. 69-92.

${ }^{4}$ P. Stępka, W. Kołodziejczak, Mechanizmy samo- $i$ wspótregulacyjne w obszarze mediów. Analiza Biura KRRiT, Warszawa 2006, nr 14, s. 3.

${ }^{5}$ A. Ogrodowczyk, L. Żebrowska, E. Murawska - Najmiec, K. Twardowska, Samoregulacja i współregulacja jako metoda rozwiq̨zywania napięć $w$ relacjach rynek - regulator, Departament Strategii Biura KRRiT, Warszawa 2018, s. 11.

${ }^{6}$ M. Płonka, Czy klienci mają szansę wpłynąć na postawy firm?, w: R. Sroka (red.), Etyka biznesu - wokół kluczowych zagadnień?, Ministerstwo Inwestycji i Rozwoju, Warszawa 2015, s. 37. 
W kontekście funkcjonowania rynku medialnego wzrasta rola podejmowanych działań samoregulacyjnych. Przyjęte rozwiązania hołdują opracowanej w latach 90. XX wieku koncepcji Media Accountability Systems (MAS) ${ }^{7}$ autorstwa C. J. Bertranda, który pojmował samoregulację, jako „wszelkie środki pozarządowe stosowane w celu uczynienia mediów odpowiedzialnymi wobec odbiorców"8. Jednym z głównych problemów związanych z deontologią jest znalezienie odpowiednich środków (o charakterze pozarządowym) mających zapewnić przestrzeganie jej zasad ${ }^{9}$. Chodzi o nakłonienie do właściwego postępowania.

\section{NORMATYWNY WYMIAR SAMOREGULACJI}

Problematyka samoregulacji od wielu lat stanowi ważny element reglamentacji i regulacji rozwiązań obowiązujących w Unii Europejskiej. W latach 80. XX wieku postrzegana jako czynnik uzupełniający stanowione prawo w sferze rynku medialnego na przestrzeni lat uległa ewolucji. Formułowanym rozwiązaniom przyświeca pogląd budowania silnej pozycji mediów, respektujących porządek prawny i etyczny. Za takim podejściem opowiadał się D. McQuaile wskazując, że istotna jest „(...) ochrona społeczeństwa i jednostki przed treściami szkodliwymi i sprzecznymi z prawem, czy z normami moralnymi i etycznymi"10. Analiza dotychczasowych rozwiązań normatywnych w zakresie prawa reklamy UE i Polski uprawnia do twierdzenia, że w obliczu ograniczonej skuteczności egzekucji prawa, powodowanej zmianami technologicznymi - na rynku medialnym, rośnie rola i znaczenie rozwiązań pozanormatywnych.

Za słuszne uznać należy powyższe podejście preferowane w Unii Europejskiej uznające za „(...) ważne instrumenty uzupełniające lub dodatkowe, nie stanowiące jednakże alternatywy dla twardego prawa, chyba że istnieje ku temu odpowiednie umocowanie w „normach podstawowych" ${ }^{11}$. Korespondują

\footnotetext{
${ }^{7}$ Media Accountability Systems oznacza - jak sprawić, by media przestrzegały przyjętych zasad.

${ }^{8}$ C. J. Bertrand, Deontologia mediów, przekł. T. Szymański, Instytut Wydawniczy PAX, Warszawa 2007.

${ }^{9}$ Tamże, s. 167.

${ }^{10}$ D. McQuail, Media and Mass communication Theory, Warszawa 2007, s. 177-179.

${ }^{11}$ Opinia Europejskiego Komitetu Ekonomiczno-Społecznego w sprawie samoregulacji i współregulacji we wspólnotowych ramach prawnych (opinia z inicjatywy własnej), Dz.U.UE.C.2015.291.29.
} 
z powyższym zasady zawarte w Strategii Lizbońskiej, Zielonej Księdze CSR (Zielony Paper: Ramy promocji dla Społecznej Odpowiedzialności Biznesu), Białej Księdze Komunikacji CSR ${ }^{12}$ czy strategii społecznej odpowiedzialności przedsiębiorstwa ${ }^{13}$. Przyjęte rozwiązania „(...) stosowane zgodnie z tradycjami prawnymi państw członkowskich mogą odegrać istotną rolę w zapewnianiu wysokiego poziomu ochrony konsumentów"14.

Analiza prowadzonych i stosowanych rozwiązań, pozwala na wyróżnienie następujących procesów samoregulacyjnych w wymiarze:

- publicznym

- i prywatnym.

Pierwsze z wymienionych znajduje wyraz w przepisach prawa powszechnie obowiązującego. 0 normatywnym podejściu decyduje fakt włączenia rozwiązań samoregulacyjnych, jako źródła rozstrzygnięć prawnych wynikających z:

- „ustanowienia przez nadrzędną strukturę (państwo, organy regulacyjne i sektorowe, Unia Europejska) określonych parametrów, które muszą być obowiązkowo przestrzegane („samoregulacja publiczna)”;

- ugruntowania $\mathrm{w}$ „(...) prawodawstwie, prawie zwyczajowym lub orzecznictwie co ma swoje źródło odpowiednio w prawie, szczególnie konstytucyjnym lub ponadnarodowym (np. prawo wspólnotowe), tradycyjnych praktykach rynkowych (obecnie określanych jako „dobre praktyki”) lub zbiorze orzeczeń sądowych"15.

${ }^{12}$ Biała księga na temat sprawowania rządów w Europie, COM(2001) 428 final (Dz.U. C 287 z 12.10.2001) oraz komunikaty w sprawie lepszego stanowienia prawa, COM(2002) 275, 276, 277 i 278 final z 5.6.2002; L. A. J. Senden, Soft Law and its implications for institutional balance in the EC" (Utrecht Law Review, IGITUR, vol. 1, nr 2, grudzień 2005 r., s. 79.

${ }^{13}$ Komisja Europejska, Komunikat Komisji do Parlamentu Europejskiego, Europejskiego Komitetu Ekonomiczno-Społecznego i Komitetu Regionów, Odnowiona strategia Unii Europejskiej na lata 2011-2014 społecznej odpowiedzialność przedsiębiorstwa, Bruksela 2011, KOM(2011) 681 wersja ostateczna.

${ }^{14}$ Pkt. 13 Dyrektywy Parlamentu Europejskiego i Rady (UE) 2018/1808 z dnia 14 listopada 2018 r. zmieniająca dyrektywę 2010/13/UE w sprawie koordynacji niektórych przepisów ustawowych, wykonawczych i administracyjnych państw członkowskich dotyczących świadczenia audiowizualnych usług medialnych (dyrektywa o audiowizualnych usługach medialnych) ze względu na zmianę sytuacji na rynku. OJ L 303, 28.11.2018.

${ }^{15}$ Pkt. 3.3 Opinia Europejskiego Komitetu Ekonomiczno-Społecznego w sprawie samoregulacji i współregulacji we wspólnotowych ramach prawnych (opinia z inicjatywy własnej), Dz.U.UE.C.2015.291.29 
Oddolne podejście uzasadnia fakt, że inicjatorem wdrażania pozanormatywnych rozwiązań są przede wszystkim przedsiębiorstwa i korporacje działające na forum międzynarodowym. Z uwagi na powyższe wyróżnić można:

- „samoregulację prywatną”,(zwaną pierwotną lub delegowaną) jako rezultat porozumień pomiędzy zainteresowanymi podmiotami

- oraz „prywatne regulacje transnarodowe”; dotyczące „(...) jedynie spraw krajowych, czy wynikające z umów podpisanych przez podmioty prywatne, przedsiębiorstwa, organizacje pozarządowe lub niezależnych ekspertów tworzących standardy techniczne, we współpracy z organizacjami międzynarodowymi lub międzyrządowymi"16.

Niezależnie od kwalifikacji, adresat przyjętych rozwiązań winien w swoich procesach decyzyjnych kierować się „(...) świadomym, zaplanowanym strategicznie etycznym działaniem organizacji/firmy na rynku, której zachowania i standardy moralne wykraczają poza prawne zobowiązania oraz wiążą się z finansową oraz organizacyjną inwestycją w praktykę etyczną" ${ }^{17}$. Wiodąca w codziennym zachowaniu jest maksyma "tak powinno być"18.

W odniesieniu do rynku audiowizualnego zaakcentować należy wpływ regulacji krajowych zawartych w porozumieniach i kartach etycznych na ponadnarodowe rozwiązania normatywne powodowane przede wszystkim zmianami technologicznymi.

W jednym z pierwszych dokumentów przyjętych w roku 1984 synchronizujących rynek audiowizualny stwierdzono, że „dobrowolna kontrola wykonywana przez branżowe organy samorządowe w celu wyeliminowania reklamy wprowadzającej w błąd, może spowodować uniknięcie odwołania się do procedur administracyjnych lub sądowych i dlatego powinna być popierana"19. Zainicjowane

${ }^{16}$ Tamże.

${ }^{17}$ M. Płonka, Czy klienci mają szansę wpłynąć na postawy firm?, w: R. Sroka (red.), Etyka biznesu - wokół kluczowych zagadnień?, Ministerstwo Inwestycji i Rozwoju, Warszawa 2015, s. 37.

${ }^{18} \mathrm{G}$. Wolska, Etyka w polskim biznesie - Moda czy konieczność?, „Zeszyty Naukowe Uniwersytetu Szczecińskiego", 2010, nr 60 (604), s. 476.

${ }^{19}$ Dyrektywa Rady z dnia 10 września 1984 r. w sprawie zbliżenia przepisów ustawowych, wykonawczych i administracyjnych Państw Członkowskich dotyczących reklamy wprowadzającej w błąd J L 250, 19.9.1984; Dyrektywa 2007/65/WE Parlamentu Europejskiego i Rady z dnia 11 grudnia 2007 r. zmieniająca dyrektywę Rady 89/552/EWG w sprawie koordynacji niektórych przepisów ustawowych, wykonawczych i administracyjnych państw członkowskich, dotyczących wykonywania telewizyjnej działalności transmisyjnej, OJ $L$ 332/27.2007. 
działania na rzecz procesów samoregulacyjnych zostały wzmocnione w kolejnych dokumentach. Począwszy od roku 1997 w kolejnych dyrektywach wskazywano na potrzebę koordynowania tego typu inicjatyw przez struktury stworzone na forum wspólnotowym ${ }^{20}$. Uznano jednocześnie, że samoregulacja nie może zastępować obowiązków prawodawczych uprawnionych organów ${ }^{21}$. Ewolucja dokonała się na przestrzeni ostatnich lat w zakresie postrzegania samoregulacji jako istotnego elementu normatywnych regulacji, znajdujących odzwierciedlenie w przepisach prawnych, a także instytucjonalnych rozwiązaniach na forum Unii Europejskiej. W dyrektywie z roku 2018 jednoznacznie opowiedziano się za opracowaniem kodeksów na forum Unijnym. 0 randze przyjętych rozwiązań przesądzają proceduralne rozwiązania. Zainteresowane podmioty przedstawiają Komisji projekt dokumentu, który wchodzi w życie po uprzednim pozytywnym zaopiniowaniu przez Komitet Kontaktowy ${ }^{22}$. 0 powszechności dostępu do zawartości treści decyduje upublicznienie dokumentu.

Gwarancje prawne stworzyły nową przestrzeń dla opracowania ponadnarodowych standardów etycznych branży medialnej, reklamowej, wpływając tym samym na katalogowanie zasad o charakterze branżowym ale i ponad krajowym, co w dobie globalizacji przepływu treści zyskuje szczególne znaczenie.

\section{ŹRÓDŁA SAMOREGULACJI W KONTEKŚCIE ETYKI BIZNESU}

Nawiązując do intelektualizmu etycznego Sokratesa, w ślad za m.in. G. H. von Wrightem i H. Schnädelbachem, podstaw podejmowanych działań samoregulacyjnych upatrywać należy w zwyczajach, obyczajach, deontologii zawodowej,

${ }^{20}$ Motyw 16 i 17 Dyrektywa Parlamentu europejskiego i Rady z dnia 6 października 1997 r. zmieniająca dyrektywę 84/450/EWG dotyczącą reklamy wprowadzającej w błąd w celu włączenia do niej reklamy porównawczej.

${ }^{21}$ Dyrektywa Parlamentu Europejskiego i Rady 2010/13/UE z dnia 10 marca 2010 r. w sprawie koordynacji niektórych przepisów ustawowych, wykonawczych i administracyjnych państw członkowskich dotyczących świadczenia audiowizualnych usług medialnych (dyrektywa o audiowizualnych usługach medialnych) (Tekst mający znaczenie dla EOG) OJ L 95, 15.4.2010.

${ }^{22}$ Art. 4a Dyrektywa Parlamentu Europejskiego i Rady (UE) 2018/1808 z dnia 14 listopada 2018 r. zmieniająca dyrektywę 2010/13/UE w sprawie koordynacji niektórych przepisów ustawowych, wykonawczych i administracyjnych państw członkowskich dotyczących świadczenia audiowizualnych usług medialnych (dyrektywa o audiowizualnych usługach medialnych) ze względu na zmianę sytuacji na rynku, PE/33/2018/REV/1, OJ L 303, 28.11.2018. 
zasadach współżycia społecznego. Docenić należy inicjatywy środowisk uwzględniające znaczenie szeroko pojmowanej moralności w biznesie. Pamiętać należy, że „Samoregulacja jest deklaracją odpowiedzialności branży za tworzone i dystrybuowane reklamy"23, ale także odzwierciedleniem preferowanych zasad branżowych.

„Zwyczaj wyraża pewne poglądy moralne, pozwalając na stwierdzenie faktu, który może być przedmiotem postępowania dowodowego, ale który nie stanowi podstawy prawnej orzeczenia"24. Dobre obyczaje są konsekwencją zwyczajów wypracowanych w danym środowisku „Dobre obyczaje to swoistego rodzaju normy moralne i zwyczajowe mające zastosowanie m.in. w działalności gospodarczej, do których prawo odsyła, a które przez to nie mieszczą się w ramach systemu prawa”25. Z tego względu „Dobre obyczaje są przeto wskazówką postępowania, istniejącą obiektywnie w poczuciu etycznym społeczeństwa (względnie, o ile idzie o uczciwość kupiecką, w poczuciu kół kupieckich)”26. Za miarę tych wymagań etycznych bierze się przeciętny poziom moralny, właściwy godziwemu życiu zarobkowemu i gospodarczemu. "Dobrym obyczajem jest (na gruncie art. 16 ust. 1 pkt 1 jak i na gruncie art. 3 ust. 1 ustawy o zwalczaniu nieuczciwej konkurencji, dalej u.z.n.k.), aby podmiot gospodarczy prowadził reklamę przejrzystą tj. jednoznacznie wskazywał reklamowany produkt. Złym obyczajem jest natomiast, gdy podmiot gospodarczy - aby wprost nie złamać zakazu prawnego - reklamuje zakazany wyrób pod pozorem reklamy wyrobu, którego reklama jest dozwolona. Jest to bowiem reklama prowadząca do zakłócenia przejrzystości działań rynkowych poprzez ukrywanie prawdziwego celu, któremu reklama służy"27. Sprzeczność z dobrymi obyczajami „(...) służy prawidłowości rozstrzygnięć przez odwołanie do znanych społecznych wartości, uelastycznienia ocen mających uzasadnienie aksjologiczne"28. Jak wcześniej podkreślono zbiory obyczajów przyjętych w danym środowisku często spisane są w formie kodeksów. Termin kodeks wywodzi się z języka łacińskiego i oznacza spis, księgę, „zbiór zasad

\footnotetext{
${ }^{23}$ https://www.radareklamy.pl/samoregulacja (dostęp 20.09.2019).

${ }^{24}$ M. Barańska, Polityka ograniczania reklamy w polskiej telewizji. Studium politologiczno - prawne. Poznań 2012, s. 358.

${ }^{25}$ Wyrok SN z dnia 18 lutego 2016 r., II CSK 282/15, OSNC 2017/1/10.

${ }^{26}$ A. Kraus, F. Zoll, Polska ustawa o zwalczaniu nieuczciwej konkurencji, Poznań 1929, s. 171.

${ }^{27}$ Wyrok SA w Krakowie z dnia 26 października 2000 r., I ACa 701/00, LEX nr 76680.

${ }^{28}$ Wyrok SN z dnia 18 lutego 2016 r., II CSK 282/15, OSNC 2017/1/10.
} 
postępowania, dotyczących np. życia towarzyskiego lub etyki zawodowej"29. Konstrukcja zapisów skodyfikowanych w kodeksach etycznych nie zawiera bowiem zakazów czy nakazów, ale wskazuje, co powinien robić każdy, kto znajdzie się w stanach opisanych ww. dokumentach.

Z kolei „Zasady współżycia społecznego odwołują się do kontekstu społecznego, zatem przede wszystkim do wartości moralnych o charakterze uniwersalnym. Z kolei dobre obyczaje na gruncie art. 3 ust. 1 u.z.n.k. rozumie się przede wszystkim w kontekście ekonomiczno-funkcjonalnym, chodzi zatem o oceny zorientowane na zapewnienie niezakłóconego funkcjonowania konkurencji przez rzetelne i niezafałszowane współzawodnictwo jakością, ceną i innymi pożądanymi przez klientów cechami oferowanych towarów i usług"30.

\section{Jako zasadniczą z punktu widzenia treści zawartych rozwiązań postrzegać należy powinność zachowań - tego co wolno$$
\text { i zabronione - która staje się ważnym }
$$ miernikiem realizacji rozwiązań i zachowań podmiotów w określonych sytuacjach.}

Deontologia zawodowa postrzegana jest, jako zbiór przestrzeganych zasad i reguł środowiskowych, o tyle kodeksy stanowią ich zmaterializowana formę. Za zasadniczą z punktu widzenia treści zawartych rozwiązań postrzegać należy powinność zachowań - tego co wolno i zabronione - która staje się ważnym miernikiem realizacji rozwiązań i zachowań podmiotów w określonych sytuacjach. Źródłem powinności zazwyczaj są reguły moralne, wartości społecznie cenione, które na kanwie prawa pisanego przyjmują formułę zasad współżycia społecznego, dobrych obyczajów ${ }^{31}$.

${ }^{29}$ https://sjp.pwn.pl/slowniki/kodeks.html.

${ }^{30}$ Wyrok SA w Warszawie z dnia 4 marca 2013 r., I ACa 923/12, LEX nr 1324807.

${ }^{31}$ Por. art. 5 Ustawy z dnia 23 kwietnia 1964 r. - Kodeks cywilny, tj. Dz. U. z 2019 r. poz. 1145,1495 ; art. 3. 16 Ustawy z dnia 16 kwietnia 1996 r. o zwalczaniu nieuczciwej konkurencji, tj. Dz. U. z 2019 r. poz. 1010, 1649. 
W potocznym rozumieniu, pojęcie etyki najczęściej wiąże się z wyznaczaniem granic w sferze moralnej, społecznej z obszarem rozwiązań pozanormatywnych, które winny być powszechnie respektowane. 0 etyce można zatem mówić jako świadomości moralnej umożliwiającej dokonywanie oceny m.in. zdarzeń, zachowań, postaw. Jako dyscyplina nauki zajmuje się badaniem tego, co jest społecznie akceptowane i negowane.

Zgodnie z treścią Encyklopedii PWN termin etyka wywodzi się z języka greckiego [gr. tá èthiká 'traktat o obyczajach' < éthos 'obyczaj', 'charakter'], termin użyty w IV w. p.n.e. przez Arystotelesa w tytule dzieła Etyka nikomachejska na oznaczenie opisowo-krytycznego studium tego, co dotyczy etosu jako ludzkiego charakteru, obyczaju, tj. utrwalonego sposobu zachowania się w środowisku życia, zamieszkania"32.

Etyka aktywności ludzkiej składa się z endomoralności i enzmoralności. Pierwszy z działów dotyczy sfery wewnętrznej, tj. norm moralnych danego rodzaju działalności, drugi norm moralnych dotyczących społecznej odpowiedzialności w danym obszarze aktywności człowieka. W kontekście prowadzonej działalności gospodarczej stanowi integralną część m.in. wymiany towarowo - handlowej. O zachowaniach etycznych można mówić w kontekście zarówno nawiązywanych transakcji pomiędzy poszczególnymi podmiotami, jak również prowadzonych kampanii marketingowych. 0 etyce można mówić zwłaszcza w kontekście realizowanych działań reklamowych. Tak postrzegana wyposaża organy przedstawicielskie do konstruowania rozwiązań, których wiodącym celem jest ochrona interesu zazwyczaj publicznego. Działania takie określane są mianem samoograniczania się środowisk lub samoregulacji. Zazwyczaj wyznaczone granice dotyczą określonego obszaru, danej dziedziny, a stanowione rozwiązania mają charakter pomocniczy względem norm prawa pisanego. Słusznie podkreśla G. Wolska, że "W ogólnym znaczeniu etyka biznesu zajmuje się oceną i określeniem standardów moralnych przystających do konkretnej sfery działalności gospodarczej. Jest ona konkretyzacją etyki ogólnej. Analogicznie zatem „Pojęcie etyki reklamy obejmuje zespół norm i zasad postępowania przyjętych w branży reklamowej, a odnoszących się do relacji między przedsiębiorstwem a jego klientami, partnerami, pracownikami i konkurentami, związanych z prowadzeniem działalności

${ }^{32}$ https://encyklopedia.pwn.pl/haslo/etyka;3898956.html (dostęp 26.092019). 
reklamowej"33. Treść rozwiązań nie odnosi się wyłącznie do kształtowania relacji między podmiotami, ale oddaje ocenie zawartość merytoryczną upowszechnianego materiału, warstwę słowną, wizualną, stosowane techniki oddziaływań.

Z uwagi na elementy składowe reklamy za interesujące uznać należy przyjętą interpretację w zakresie pojęcia etyki słowa. Zdaniem I. Płóciennik i D. Podlawskiej: „pierwszą zasadą etyki słowa jest pozostawienie adresatowi możliwości wybierania między mówieniem a milczeniem, między odbiorem a nieodbieraniem komunikatu. Nikogo nie można zmuszać do słuchania tekstu i reagowania na niego w jakikolwiek sposób”34. Z tego względu za istotne uznaje się „konstruowanie wypowiedzi z poszanowaniem odbiorcy, uwzględnianiem jego przyzwyczajeń i poglądów, nienarzucaniu mu swojego zdania, danie mu możliwości wyboru postawy. Etyka słowa postuluje, abyśmy mówili w sposób uczciwy i przyjazny wobec naszego rozmówcy"35. Interpretacja zasad etycznych modyfikowana jest m.in. zmianami zachodzącymi w społeczeństwie, wzrostem tolerancji względem różnych zachowań czy postaw.

Etyka zatem wzmacnia uprawnienia adresatów przekazu do weryfikowania treści przekazu z punktu widzenia jej zawartości i zgodności ze społecznymi oczekiwaniami. O skuteczności decydować będzie wachlarz rozwiązań egzekucyjnych: monitorowanie, sankcjonowanie nieprawidłowości. Skuteczność obowiązujących rozwiązań wzmacnia zaangażowanie społeczeństwa w zakresie krytycznej oceny prezentowanych treści np. reklamowych.. Opracowane przez różne organizacje i środowiska postrzegane są jako element działań promocyjnych - pozytywne kształtowanie wizerunku.

W sferze reklamy nie tylko przedmiotowa branża inauguruje działania na rzecz tworzenia reglamentacji pozanormatywnej, także środowiska producentów szczególnie artykułów spożywczych, zabawek, piwa, ale coraz częściej mieszkańcy poszczególnych krajów zainteresowani są taką formą aktywności obywatelskiej. Przywołać w tym miejscu należy zainaugurowane przez społeczność Irlandii przedsięwzięcia na rzecz eliminowania w reklamach telewizyjnych tzw.

${ }^{33}$ W. Gasparski, Etyka biznesu - szkice do portretu, (w:) Dietl J., Gasparski W. (red.), Etyka biznesu, Wydawnictwo Naukowe PWN, Warszawa 1997, s. 17.

${ }^{34}$ Hasło: etyka słowa (języka), [w:] Słownik wiedzy o języku, I. Płóciennik, D. Podlawska, Wyd. Park, Bielsko-Biała 2004, s. 64.

${ }^{35}$ Hasło: kultura języka, http:// https://polki.pl/rodzina/slownik,kultura-jezyka,14523,slowo.html (dostęp 28.08.2019 r.). 
„śmieci żywieniowych”. Połączenie hard law i soft law pozwala na prowadzenie kontroli instytucjonalnej przez uprawnione do tego organy władzy oraz podmioty cieszące się autorytetem $\mathrm{w}$ danym środowisku.

\section{POJĘCIE REKLAMY}

Termin reklama nie ma bezwzględnie obowiązującej definicji. W ujęciu socjologicznym przyjmuje się m.in., że jest to zjawisko towarzyszące decyzjom konsumenckim, kształtujące relacje pomiędzy podmiotami gospodarczymi ${ }^{36}$. W ujęciu prawnym to ogół zasad obowiązujących w zakresie treści, nośników a także terminu emisji wypowiedzi reklamowych $\mathrm{w}$ danym środowisku, społeczeństwie, których brak przestrzegania rodzi określone skutki. Egzekucyjność, a zwłaszcza jej skuteczność będzie decydowała o zasadności ustanowionych rozwiązań.

W kontekście psychologicznym to zbiór zasad wyznaczający granice dozwolonych praktyk w sferze wizualnej, werbalnej odnoszących się często do emocji, stanowiących element perswazji czy manipulacji wpływających na decyzje i zachowania adresatów treści na poziomie świadomym lub nieświadomym. 0 ile rozwiązania prawne czy ekonomiczne odnoszą się nie tylko do ludzi, organizacji, o tyle uwarunkowania psychologiczne kojarzone są przede wszystkim z człowiekiem. „Jednak - jak zauważają badacze przekazu reklamowego - dla znacznej części nadawców komunikatów reklamowych prawda i elementarna uczciwość wobec klienta nie są głównymi wyznacznikami wykorzystywanymi w procesie promowania produktu. Perswazja jawna często zastąpiona zostaje (o wiele niebezpieczniejszą) perswazją ukrytą"37. Psychologia przekazu zaczyna odgrywać pierwszorzędną rolę. Perswazja werbalna coraz częściej zostaje zastąpione perswazją ukrytą w semiosferach przekazu. Zamiast nakłaniać, wzbudza się zainteresowanie odbiorcy. W miejsce etyki pojawia się estetyka. Treści artystyczne przesłaniają wartości wychowawcze i poznawcze. Zgodnie z koncepcją Umberto Eco odnoszącą się do wielokodowości przekazu reklamowego, warstwa wizualna

${ }^{36}$ Zob. M. Barańska, Polityka ograniczania reklamy $w$ polskiej telewizji. Studium politologiczno-prawne, Wydawnictwo WNPiD UAM, Poznań 2012; W. Wszołek, Reklama operacjonalizacja pojęcia, Wydawnictwo LIBRON - Filip Lohner, Wrocław 2015; K. Grzybczyk, Prawo reklamy, Wolters Kluwer, Wrocław 2015.

${ }^{37}$ E. Sanecka, Psychologiczne mechanizmy oddziaływania reklamy a manipulacja $w$ reklamie. Katowice, 2012, s. 5. 
reklamy zaczyna przesłaniać warstwę werbalną, na poziomie której pojawia się retoryka i erystyka. To właśnie techniki perswazyjne i argumentacyjne pozwalają na ukazanie w reklamach rzeczywistości społecznej, jako ściśle określonej i jednoznacznej. Stąd już tylko krok do operowania stereotypami i utrwalania ich w świadomości społecznej"38.

Analiza ekonomiczna sytuuje reklamę m.in. jako element wpływający na sukces działalności przedsiębiorstwa. Wielość zaproponowanych rozwiązań uzasadnia stanowisko, że reklamą jest wypowiedź dotycząca towarów lub usług, która poprzez stosowane środki perswazyjne: wizualne, werbalne wpływa na decyzje konsumentów w zakresie nabywania towarów lub usług. Osobliwością reklamy jest element zachęty do zakupu. Jego prawidłowy dobór wpływa na efektywność i skuteczność prowadzonej kampanii, decydujący o pozycji ekonomicznej przedsiębiorstwa, jak i satysfakcji, poczuciu zadowolenia nabywcy.

Charakterystykę pojęcia reklamy można znaleźć w Kodeksie Etyki Reklamy ${ }^{39}$ opracowanym przez Radę Reklamy i Komisję Etyki Reklamy: „reklama - przekaz zawierający w szczególności informację lub wypowiedź, zwłaszcza odpłatny lub za wynagrodzeniem w innej formie, towarzyszący czyjejkolwiek działalności, mający na celu zwiększenie zbytu produktów, inną formę korzystania z nich lub osiągnięcie innego efektu, które są pożądane przez reklamodawcę. Do reklamy zalicza się również promocję sprzedaży, oferty kierowane do odbiorców za pomocą marketingu bezpośredniego lub sponsoring. Dla uniknięcia wątpliwości reklamą w rozumieniu Kodeksu nie jest: (1) przekaz mający na celu propagowanie pożądanych społecznie zachowań, jeżeli nie jest jednocześnie związany z promocją reklamodawcy, przedmiotu jego działalności, jego produktu lub produktów pozostających w jego dyspozycji; (2) przekaz będący elementem kampanii wyborczej lub referendalnej, w tym również przekaz o treści propagującej określone zachowanie odbiorców w wyborach lub referendum; (3) przekaz, także publiczny, pochodzący od podmiotu (np. spółki kapitałowej, fundacji), wymagany obowiązującymi przepisami prawa lub skierowany do jego organów, udziałowców lub potencjalnych udziałowców, w szczególności w zakresie obejmującym stan faktyczny, prawny, finansowy, a także w zakresie informacji dotyczących akcji i innych papierów wartościowych, kwitów depozytowych, znaków legitymacyjnych lub innych jednostek udziałowych

${ }^{38}$ Tamże.

${ }^{39}$ Kodeks Etyki Reklamy, Warszawa, 11 września 2019 r., https://www.radareklamy.pl/ pełna-tresc-ker (dostęp 20.09.2019). 
(uczestnictwa) w odniesieniu do: tego podmiotu, podmiotów z nim powiązanych bezpośrednio lub pośrednio" ${ }^{\prime 4}$.

Reklama zatem jest komunikatem zawierający ładunek informacyjny i perswazyjny, treści manipulacyjne, które mogą być zawarte w warstwie werbalnej i niewerbalnej, nadawany przez reklamodawcę lub dostawcę treści przekazu albo dystrybuowany w innej formie, adresowany do nieograniczonej liczby podmiotów, zgodny z prawem pisanym i etyką.

\section{ŹRÓDŁA UWARUNKOWAŃ ETYCZNYCH I ICH INSTYTUCJONALIZACJA}

\section{Międzynarodowy kontekst}

Opracowanie ujednoliconych norm etycznych w globalnym wymiarze stanowi konsekwencję spójności respektowania zasad przez różne środowiska, wyznaczania priorytetów, hierarchizowania wartości, zważywszy na fakt, że ich opracowanie uwarunkowane jest trudnościami wynikającymi z różnic i sprzeczności interesów poszczególnych podmiotów na danym obszarze. Treść rozwiązań etycznych kładzie nacisk na zapewnienie, by reklama nie wprowadzała w błąd i chroniła przed nieuczciwą zawartością treści adresowanych do jej odbiorców. $\mathrm{Z}$ uwagi na powyższe, tym bardziej docenić należy wszelkie procesy zmierzające do harmonizacji rozwiązań na forum międzynarodowym.

Wraz z rozwojem wymiany towarowo-handlowej w latach 60. XX wieku i wzrostem znaczenia reklamy jako narzędzia działań marketingowych, zainaugurowano przedsięwzięcia na rzecz kreowania rozwiązań samoregulacyjnych. Przyjęty przez Międzynarodową Izbę Handlową w roku 1966 Międzynarodowy Kodeks Etyki Reklamy ${ }^{41}$ potwierdził, że mimo różnorodności systemów wartości obowiązujących w poszczególnych krajach, członkowie stowarzyszeni w Izbie dokonali polaryzacji stanowisk opracowując wspólne zasady i wskazując na instytucje stojące na straży ich przestrzegania. Składający się z dwóch części „Kodeks” zawiera rozwiązania dotyczące pojęcia, treści - zasad reklamy, druga zaś część

${ }^{40}$ Zob. http://www.radareklamy.org/kodeks-etyki-reklamy.html?showall=\&start=2 (dostęp 8.09.2014).

${ }^{41}$ W roku 1987 znowelizowano tresce kodeksu dostosowując treść zapisów do wymogów rynku reklamy. Dodać należy, że Międzynarodową Izbe Handlową reprezentuje interesy światowego biznesu względem rządów i innych organizacji międzynarodowych. Zob. https:// www.iccpolska.pl (dostęp 28.08.2019 r.). 
reglamentuje relacje pomiędzy przemysłem reklamowym i klientami. Szczegółowe postanowienia dotyczące wybranych branż zawarto w załączniku. Słusznie podkreślono, że „W reklamie ma obowiązywać zasada uczciwej konkurencji w takim sensie, jak jest to powszechnie rozumiane i przyjęte w stosunkach handlowych. Powodzenie reklamy zależy od zdobytego przez nią zaufania ogółu. Dlatego też działalność reklamowa powinna zmierzać do zwiększenia tego zaufania"42. Poza wymienioną za istotne uznano przestrzeganie zasady przyzwoitości, moralności publicznej, uzasadnionej i racjonalnej argumentacji, np. odwoływanie się do statystki czy powoływanie się na autorytety naukowe, treści nie powinny wywoływać lęku i strachu czy wykorzystywać łatwowierności u odbiorców, zwłaszcza najmłodszych. Mimo upływu czasu wciąż aktualne są rozwiązania dotyczące reklamy porównawczej czy naśladowniczej. Podmioty praktykujące taka formę oddziaływania nie mogą narażać na zniesławienie czy śmieszność. Wyrazem troski o dobro szczególnego adresata reklamy są rozwiązania dotyczące treści adresowanych do osób chorych, głównych nabywców wyrobów farmaceutycznych. Za wiodące uznano piętnowanie tych wypowiedzi, które budują fałszywe przeświadczenia niemal natychmiastowego uzdrowienia, przywrócenia stanu bez chorobowego.

\section{Wyrazem troski o dobro szczególnego adresata reklamy są rozwiązania dotyczące treści adresowanych do osób chorych, głównych nabywców wyrobów farmaceutycznych.}

Oceniając zasadność zawartości treści kodeksu etycznego wskazać w pierwszej kolejności należy ponadczasowy wymiar, indyferentność prezentowanych stanowisk, które nie straciły na znaczeniu pomimo upływu ponad 50 lat od ich upowszechnienia. Dodać należy, że autorzy wyznaczyli pewną płaszczyznę reglamentacji nie ograniczając także na przyszłość podejmowania działań przez inne środowiska, zarówno w płaszczyźnie międzynarodowej, jak i systemach krajowych ${ }^{43}$.

${ }^{42}$ Międzynarodowy Kodeks Etyki Reklamy, s. 60.

${ }^{43}$ Szerzej na temat kodeksów etycznych m.in. M. Barańska, Polityka ograniczania reklamy w polskiej telewizji. Studium politologiczno - prawne, Poznań 2012, s. 357-399. 


\section{Rozwiązania krajowe}

Przemiany społeczno-ekonomiczne lat 80. i 90. XX wieku w Polsce, wejście w życie zasad wolnorynkowej, liberalnej gospodarki, sprawiły, że opracowano nie tylko rozwiązania normatywne dotyczące reklamy, ale także podjęto wyzwanie skodyfikowania zasad etycznych. Już w roku 1995 nadawcy przekazów audiowizualnych podpisali „Kartę etyczną mediów”. „ (...) kierując się zasadą dobra wspólnego, świadomi roli mediów w życiu człowieka i społeczeństwa obywatelskiego, przyjmują tę kartę oraz deklarują, że w swojej pracy kierować się będą następującymi zasadami: (...)"44 m.in. prawdy, obiektywizmu, uczciwości. Upływ czasu pokazał, że w praktyce Karta była stosowana w niewielkim stopniu, pomimo upoważnienia Rady do podejmowania czynności kontrolnych.

Z inicjatywy Polskiej Korporacji Reklamy powołano Koalicję Wolnego Słowa VOX, która opracowała wstępny projekt rozwiązań etycznych, który ostatecznie został przyjęty w roku 1996 przez Związek Stowarzyszeń Rada Reklamy ${ }^{45}$; jest instytucjonalnym kontynuatorem stanowionych praw etycznych w obszarze reklamy w Polsce. „Wg. obowiązującej od 19 stycznia 2018 r. definicji, sygnatariuszami Kodeksu Etyki Reklamy są:

- podmioty, którym przysługuje prawo do znaku towarowego „Reklamuję etycznie",

- członkowie organizacji zrzeszonych w Związku Stowarzyszeń Rady Reklamy, które zastrzegły w swoich wewnętrznych regulacjach, że Kodeks Etyki Reklamy obowiązuje wszystkich ich członków.

- członkowie organizacji zrzeszonych, którzy zobowiązali się na podstawie odrębnie zgłoszonych oświadczeń woli do przestrzegania Kodeksu Etyki Reklamy"46.

${ }^{44}$ Karta etyczna mediów, http://www.dziennikarzerp.pl/wp-content/uploads/2010/ 06/karta_dziennikarzy.pdf (dostęp: 28.08.2019 r.).

${ }^{45}$ Statut Związku Stowarzyszeń Rada Reklamy, Tekst jednolity z 25 października 2018 r. wpisany do KRS 6 kwietnia 2019 r., https://www.radareklamy.pl/statut?showall= (dostęp 28.08.2019 r.).

${ }^{46}$ Sygnatariusze. http.//www.radareklamy.pl/sygnatariusze, 20.08.2019 r. Stowarzyszenie Komunikacji Marketingowej SAR, Międzynarodowe Stowarzyszenie Reklamy w Polsce (IAA), Związek Pracodawców Prywatnych Mediów, Polska Federacja Producentów Żywności, Związek Pracodawców Przemysłu Piwowarskiego - Browary Polskie, Związek Pracodawców Branży Internetowej IAB Polska, Stowarzyszenie Polskich Producentów Wyrobów 
Dodać należy, że członkowie stowarzyszenia podpisują licencję na okres jednego roku, na mocy której mogą posługiwać się w prowadzonych działaniach reklamowych znakiem „Reklamuję etycznie” oraz „Sygnatariusz KER” ${ }^{47}$. Wnioskować zatem należy, że działanie sprzeczne z etyką sankcjonowane jest m.in. pozbawieniem prawa do używania powyższego oznaczenia.

\section{Polski Kodeks Etyki Reklamowej nawiązuje w zakresie podstawowym do treści przyjętych w Międzynarodowym Kodeksie Reklamy.}

Polski Kodeks Etyki Reklamowej nawiązuje w zakresie podstawowym do treści przyjętych w Międzynarodowym Kodeksie Reklamy. Indyferentność rozwiązań powodowana była przede wszystkim zmianami zachodzącymi w sferze gospodarczej, nowymi praktykami, ofertą sprzedaży wyrobów i popularnością niektórych produktów, ze szczególnym uwzględnieniem używek, ale również zmianami technologicznymi, które stworzyły nowe perspektywy dla techniki i formy konstruowania przekazów reklamowych. Zwrócić należy uwagę, że w kolejnych zmianach uwzględniono powszechne oczekiwanie społeczeństwa ukierunkowane m.in. na ochronę najmłodszego odbiorcy. Wprowadzono m.in. reglamentację dotyczącą treści reklam adresowanych do dzieci poprzez eliminowanie sformułowań „ wszystkie inne dzieci już to mają” lub „wszyscy chłopcy/dziewczynki bawią się zabawkami”, co mogłoby stwarzać nietrafne postrzeganie wartości, sugerować ograniczony dostęp do produktu, a co za tym idzie wykorzystywać łatwowierność dzieci i budować błędne przekonanie o rzeczywistości ${ }^{48}$.

O skuteczności prawa nie decyduje ilość obowiązujących rozwiązań, ale skuteczność egzekucji. Funkcje kontrolne sprawuje Komisja Etyki Reklamy (KER), składająca się z „ (...) 30 arbitrów powoływanych przez przedstawicieli trzech

Czekoladowych i Cukierniczych Polbisco, Polskie Stowarzyszenie Przemysłu Kosmetycznego i Detergentowego, Polski Związek Przemysłu Kosmetycznego.

${ }^{47}$ Zob. https://www.radareklamy.pl/jak-dziala-samoregulacja (dostęp 28.08.2019 r.).

${ }^{48}$ Ostatnie zmiany wprowadzono w roku 2018. Art. 21-32 Kodeksu Etyki Reklamy. Dotyczy przede wszytki reklamy adresowanej do dzieci. https://www.radareklamy.pl/images/ Nowe_Procedury/Kodeks_Etyki_Reklamy_19.01.2018.pdf (28.08.2019 r.) 
środowisk związanych z reklamą: reklamodawców, media oraz agencje reklamowe. Zarząd Rady Reklamy powołuje dodatkowo Arbitra-referenta, który odpowiada za badanie spełniania przez wpływające skargi wymogów formalnych, wspomaga również pracę zespołów orzekających. Osoby zasiadające w KER są ekspertami z wieloletnim doświadczeniem w dziedzinie reklamy, mediów oraz marketingu" ${ }^{\prime 2}$. Przedmiot analizy stanowią reklamy upowszechniane w mediach elektronicznych i nośnikach outdoorowych. Inicjatorem postępowania może być każdy, kto uzna że treść reklamy jest sprzeczna z etyką. System elektroniczny umożliwia zainteresowanym podmiotom złożenie skargi, jak również prawne przeprowadzenie procedury jej rozpatrzenia ${ }^{50}$. Takie rozwiązanie, zdaniem autorek nie pozostaje bez wpływu na szybkość załatwienia sprawy. Negatywnym następstwem długofalowości realizowanego postępowania może być brak możliwości zastosowania treści orzeczenia, z powodu upływu terminu realizacji kampanii reklamowej. Chcąc przeciwdziałać tego typu praktykom za celowe uznano rzetelne i sprawne działanie na rzecz rozstrzygania spraw (por. Schemat 1 . Procesu rozpatrywania skargi).

We wstępnej fazie postępowania - wyznaczony przez Przewodniczącego Rady Etyki Reklamy arbiter - referent poddaje skargę ocenie formalnoprawnej. Wszelkie braki winny być uzupełnione w terminie 10 dni. Bezskuteczny upływ czasu do uzupełnienia treści skargi czy negatywna ocena powodowana uchybieniami formalnymi np. niewłaściwością organu uprawnionego do rozpatrzenia sprawy skutkować może odrzuceniem skargi. O oddaleniu przesądza brak odpowiedniej argumentacji zawartej w treści skargi. Pozytywna ocena wstępnej analizy umożliwia dalsze procedowanie. W odniesieniu do nie sygnatariuszy kontynuowanie postępowania wymaga uzyskania akceptacji w terminie $10 \mathrm{dni}$.

Tryb postępowania określony w „Regulaminie rozpatrywania skarg” opiera się na zasadzie kontradyktoryjności stron. Podmioty, których skarga dotyczy mają prawo zapoznać się z zarzutami i ustosunkować się, wnosząc odpowiedź na zarzuty wraz z załącznikami. Wyznaczony arbiter - referent po zapoznaniu się ze zgromadzonym materiałem, przekazuje sprawę przewodniczącemu, który wyznacza

${ }^{49}$ Rada reklamy: https://www.radareklamy.pl/komisja-etyki-reklamy (dostęp 28.08. 2019 r.).

${ }^{50}$ Por. Regulamin Rozpatrywania Skarg z dnia 19.01.2018 r. ze zm. z dn. 11.05.2018 r. dot. pkt. 24, https://www.radareklamy.pl/images/Dokumenty/RRS_19.01.2018_ze_zm._11.05.2018. pdf, (dostęp 28.08.2019 r.) 
Schemat procesu rozpatrywania skarg

wg Regulaminu Rozpatrywania Skarg z dn. 19.01.2018 r.

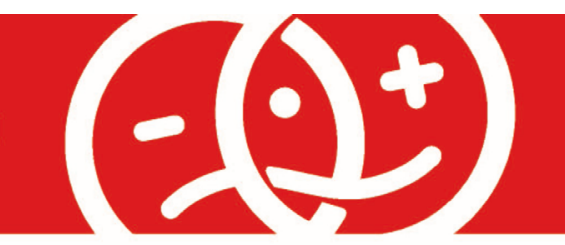

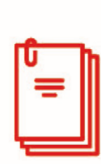

KONSUMENT / PRZEDSIĘBIORCA

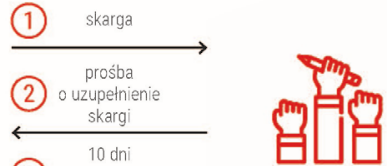

BIURO RR
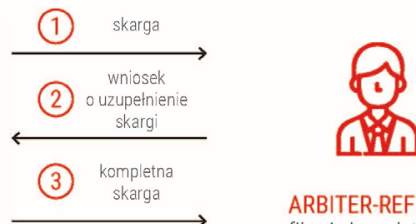

ARBITER-REFERENT weryfikacja kompletności skargi

SPRAWDZENIE CZY SKARŻONY JEST SYGNATARIUSZEM CZY JEST NIE-SYGNATARIUSZEM (zgodnie pkt 12 Regulaminu Rozpatrywania Skarg)

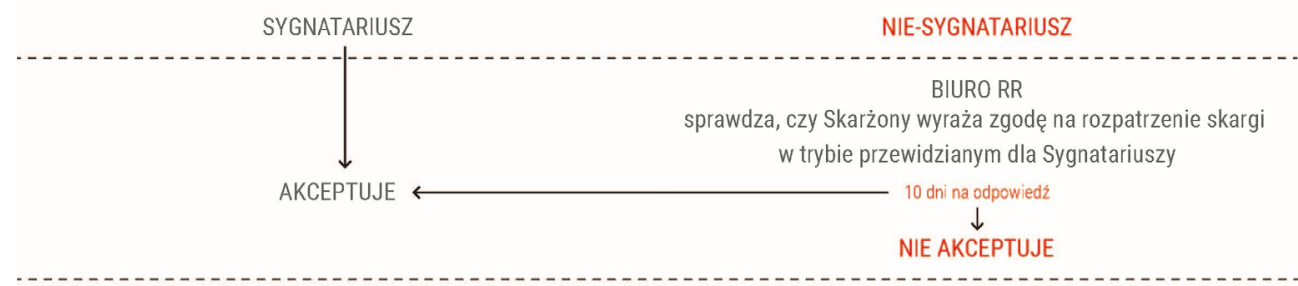

BIURO RR

wysyła zawiadomienie do Skarżonego o skierowaniu

sprawy do KER

10 dni na odpowiedź Skarżonego

ODPOWIEDŹ / WYJAŚNIENIE SKARŻONEGO

BIURO RR

przekazuje odpowiedź / wyjaśnienie do ARBITRA-REFERENTA

PRZEWODNICZĄCY KER WYZNACZA ZESPÓŁ ORZEKAJĄCY

PRZEWODNICZACCY KER WYZNACZA TERMIN POSIEDZENIA

Biuro RR informuje Skarżącego i Skarżonego o terminie posiedzenia i składzie zespołu orzekającego

POSIEDZENIE ZESPOŁU ORZEKAJACEGO ( $z$ dobrowolnym udziałem SYGNATARIUSZA lub SKARŻONEGO akceptującego procedurę dla SYGNATARIUSZY lub bez udziału NIE-SYGNATARIUSZA)

ZESPÓt ORZEKAJĄCY WYDAJE UCHWAŁĘ

ZESPÓŁ ORZEKAJĄCY WYDAJE OPINIĘ

PUBLIKACJA UCHWALY / OPINII na wWW.radareklamy.pI WYSYŁKA UCHWAL / OPINII DO STRON

$10 \mathrm{dni}$ na odwołanie od uchwały (Skarżący i Sygnatariusz)

Źródło: Schemat procesu rozpatrywania skarg https://www.radareklamy.pl/images/ Nowe_Procedury/Schemat_procesu_rozpatrywania_skarg_nowy.jpg (dostęp 22.10.2021 r.) 
zespół orzekający i termin posiedzenia. Ocena zgromadzonego materiału, stanowi podstawę dla rozstrzygnięcia. Uznając zasadność treści skargi, może stwierdzić, że reklama jest zgodna z obowiązującymi normami, uznać konieczność wprowadzenia zmian w reklamie celem uzyskania stanu zgodnego z etyką w najbliższym możliwym terminie lub wstrzymać emisję reklamy. Dodatkowo podmioty dysponując prawem używania certyfikatu „Reklamuję Etycznie” i „Sygnatariusz KER”51 przyznawanych przez Radę Reklamy mogą być pozbawione jego używania. (zob. rys. 1)

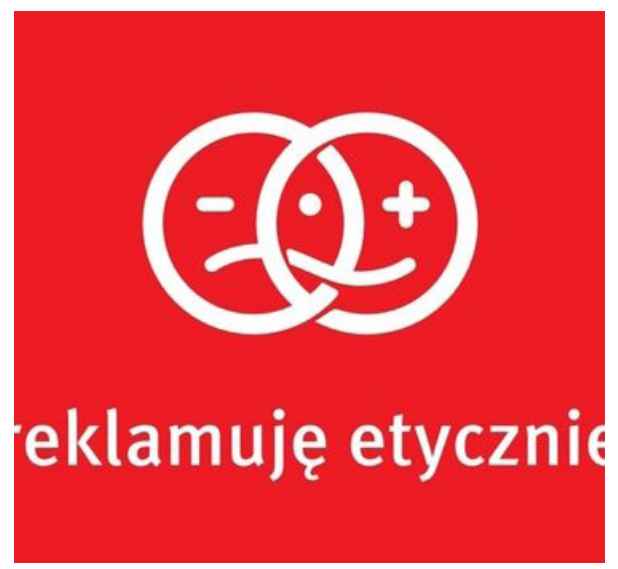

Rys. 1. Certyfikat „Reklamuje etycznie: https://www.radareklamy.pl/images/Nowe_ Procedury/Schemat_procesu_rozpatrywania_skarg_nowy.jpg (dostęp; 22.10.2021 r.)

0 treści orzeczenia powiadamiane są wszystkie zainteresowane podmioty, w tym reklamodawca, producent, agencja produkująca dany przekaz, inne podmioty rozpowszechniające przekaz ${ }^{52}$. Tak szeroki katalog podmiotów, którym doręczana jest treść rozstrzygnięcia sprzyjać ma szybkości wdrożenia zawartych w nim postanowień do praktyki.

Powszechnie stosowana zasada dwuinstancyjności procedury w prawie pisanym, została zastosowana także do „Kodeksu etycznego”. W terminie $10 \mathrm{dni}$ od otrzymania treści decyzji zainteresowane podmioty mogą odwołać się do Zespołu

${ }^{51}$ Prawo do używania certyfikatów przysługuje podmiotom, które podpisały licencję na okres 12 miesięcy i opłaciły. Wysokość opłaty uzależniona jest od „(...)od wydatków/wpływów reklamowych za rok poprzedni (rate card) według zestawienia Kantar Media". Finansowanie, https://www.radareklamy.pl/jak-dziala-samoregulacja (dostęp 20.09.2019 r.)

5237 Regulaminu Rozpatrywania Skarg przez Radę Reklamy. 
Odwoławczego. Przyjęte rozwiązanie jest ostateczne i nie służy żaden środek zaskarżenia.

Gwarantem jawności procedury jest także obowiązek publikowania decyzji na stronach Rady. W ocenie autorek takie działanie sprzyja procesom edukacyjnym, ale również ma wymiar represyjny.

Odpowiedzialność środowisk medialnych za przekaz reklamowy przyczyniła się do podpisania 29 października 2014 r., „Porozumienia nadawców dotyczących artykułów spożywczych lub napojów zawierających składniki, których obecność w nadmiernych ilościach w codziennej diecie jest niewskazana"53. Ogólnokrajowi nadawcy telewizyjni, oraz The Walt Disney Company, Krajowa Rada Radiofonii i Telewizji, Związek Stowarzyszeń Rady Reklamy, zobowiązali się do nieemitowania przed programami adresowanymi do dzieci poniżej 12 roku życia reklam artykułów spożywczych zawierających składniki, których nadmierna ilość w diecie codziennej dzieci może powodować negatywne skutki. Powyższa kwestia jest przede wszystkim przedmiotem rozwiązań zawartych $\mathrm{w}$ prawie pisanym ${ }^{54}$. Wskazani wyżej sygnatariusze „Porozumienia” za fundamentalne dla powodzenia stanowionych zobowiązań uznali wyznaczenie kryteriów żywieniowych.

Kierując się rozwiązaniami obowiązującymi w Unii Europejskiej, Polska Federacja Producentów Żywności i Związek Pracodawców opracowali katalog produktów, zaaprobowany przez Instytut Ministerstwa Zdrowia i Instytut Żywności i Żywienia - sklasyfikowanych w 10 kategoriach, których skład zobowiązywał reklamodawców- producentów do zaprezentowania nadawcy oświadczenia żywieniowego $^{55}$ o produkcie przed emisją reklamy (zob. Schemat 2. Procedury postępowania).

${ }^{53}$ https://www.radareklamy.pl/images/Dokumenty/zywnosc/porozumienie $\% 20$ nadawcow.pdf (dostęp 21.10.2021).

${ }^{54}$ Rozporządzenie Parlamentu Europejskiego i Rady (UE) nr 1169/2011 z dnia 25 października w sprawie przekazywania konsumentom informacji na temat żywności (Dz. Urz. WE. L 304/18 z 22.11.2011); Dyrektywa 2005/29/WE Parlamentu Europejskiego i Rady z dnia 11 maja 2005r. w sprawie nieuczciwych praktyk handlowych stosowanych przez przedsiębiorstwa wobec konsumentów na rynku wewnętrznym oraz zmieniająca dyrektywę Rady 84/450/EWG, dyrektywy 97/7/WE i 2002/65/WE Parlamentu Europejskiego i Rady oraz rozporządzenie (WE) 2006/2004 (Dz. Urz. WE L 149 z 11.06.2005).

55 Źródłem prawnym oświadczeń żywieniowych i zdrowotnych jest Rozporządzenie Parlamentu Europejskiego i Rady (WE) nr 1924/2006 z 20 grudnia 2006r. w sprawie oświadczeń żywieniowych i zdrowotnych dotyczących żywności. Organem uprawnionym do ich rejestracji jest Komisja Europejska. 


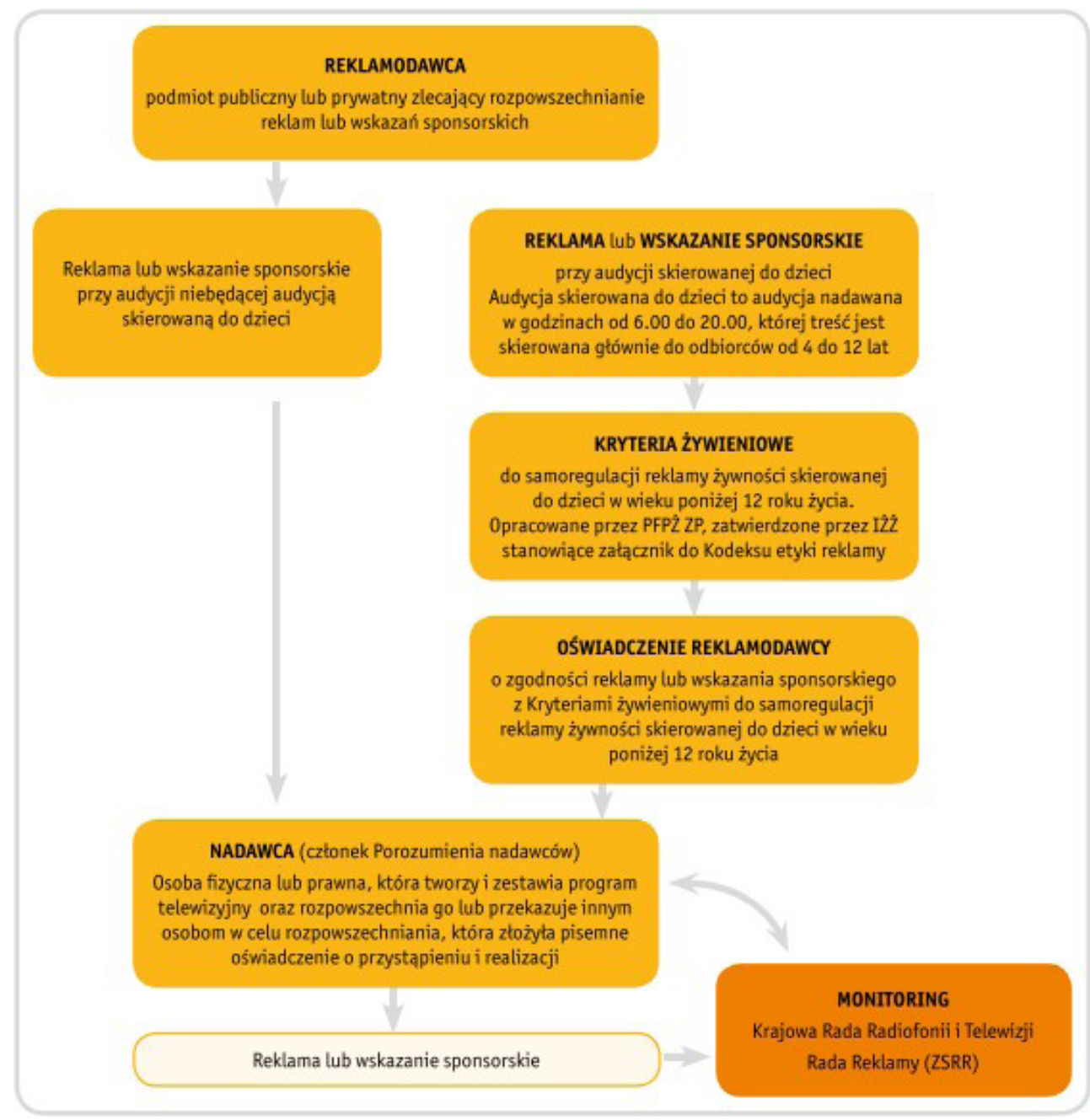

Schemat 2. Procedury postępowania

Źródło: A. Gantner, M. Tomaszewska-Pielacha, Polska Federacja Producentów Żywności Związek Pracodawców, Trzy lata funkcjonowania w Polsce samoregulacji w zakresie reklamy żywności skierowanej do dzieci, https://www. pfpz.pl/trzy-lata-funkcjonowania-w-polsce-samoregulacji-w-zakresie-reklamyzywnosci-skierowanej-do-dzieci-15406; (dostęp 28.08.2019 r.)

Jak wynika z powyższego schematu, decyzję o emisji reklamy ostatecznie podejmuje nadawca, zaś KRRiT, jako organ wyposażony w kompetencje kontrolne, 
monitoruje ofertę programową nadawców i inne przekazy handlowe, sankcjonując ich niezgodność z przyjętymi rozwiązaniami.

W tym nurcie opublikowano 11 wrześniu 2019 roku „Kartę ochrony dzieci w reklamie", której treść stanowi integralną część Polskiego Kodeksu Etyki Reklamowej. Za istotne uznano eliminowanie m.in. „(...) sceny przemocy fizycznej i psychicznej, problematyczne relacje rodzinne - np. zaniedbywanie dziecka - sceny zachęcające do konfliktów, motywy nadmiernej konsumpcji i konsumpcyjnego stylu życia, podteksty seksualne - także żartobliwe - oraz treści dyskryminujące ze względu na rasę, płeć, narodowość, przekonania religijne lub niepełnosprawnośćn" ${ }^{\prime \prime}$, a także sceny zachęcające do konfliktu zarówno z rówieśnikami, jak i osobami dorosłymi, czy brakiem odpowiedzialności za podejmowane działania ${ }^{57}$. Jest to zdaniem autorek jeden z pierwszych dokumentów określający udział dzieci w castingach czy występowanie w roli aktorów wcielających się w bohaterów reklam.

Każdy ze wskazanych dokumentów podkreśla m.in. potrzebę ochrony konsumenta przed reklamą wprowadzającą w błąd, ochronę najmłodszego odbiorcy przed wykorzystywaniem łatwowierności dzieci, deklaruje podejmowanie działań na rzecz przeciwdziała dyskryminacji płci, rasy, wieku, koloru skóry.

Doświadczenia ostatnich lat ukazują, że coraz więcej instytucji i organizacji dąży do opracowania obowiązujących w danej branży zwyczajów w formie zmaterializowanej, np. Kodeks Etyki Reklamy i Komunikacji Marketingowej Spółki Lubelski Węgiel „Bogdanka” S.A. w Bogdance ${ }^{58}$. W wielu z nich kwestia reklamy nie ma charteru wiodącego. Stanowione rozwiązania skoncentrowane są często na eksponowaniu specyfiki danej dziedziny. Dobrowolny Kodeks Postępowania w Zakresie Reklamy i Promocji Piwa, przyjęty przez polskie browary w dn. 8 lipca 1998 (aktualny tytuł Kodeks Reklamowy Związku Pracodawców Przemysłu Piwowarskiego „Browary Polskie”) - stanowi integralną cześć kodeksu Etyki Reklamy - wpisuje się w politykę ochrony konsumenta, zwłaszcza gdy idzie o ochronę najmłodszych odbiorców przekazów reklamowych. Zobowiązuje nie tylko do rzetelnego informowania o wyrobie, ale wskazuje na techniczne granice emisji

${ }^{56}$ Dzieci lepiej chronione przed reklamami. Standardy przekazów marketingowych mają obowiązywać też $w$ internecie https://serwisy.gazetaprawna.pl/media/artykuly /1429756,jak-chronic-dzieci-przed-reklamami.html (dostęp 12.09.2019 r.)

${ }^{57}$ Por. Rozdział 2 Załącznik Nr 3 Karta Ochrony Dzieci w Reklamie, Warszawa, 11 września $2019 \mathrm{r}$.

${ }^{58}$ https://www.lw.com.pl/pl,2,s370,kodeks_etyki_reklamy.html (dostęp: 30.08.2019 r.). 
spotów reklamowych popularyzujących piwo ${ }^{59}$. Należy przyznać, że wiele rozwiązań znajduje swoje odzwierciedlenie w prawie pisanym. Działania na rzecz zdrowego stylu życia, zmiana kultury spożywania napojów alkoholowych zobowiązują reklamodawców do poszukiwania takich form zachwalania wyrobów, które wpisują się w nurt odpowiedzialnej konsumpcji alkoholu, nowoczesnego zrównoważonego stylu życia, ograniczania skutków nadmiernego spożywania alkoholu.

Na ile, jednak skuteczne będą wydawane rozstrzygnięcia, zależy od czynnika wolitywnego ich adresatów. Sankcje mają wymiar społeczny i/ lub są źródłem negatywnych opinii w środowisku. Za podstawowe uznać należy, dojrzałość i odpowiedzialność za przyjęte zobowiązania, jako podstawę sankcjonowania negatywnych zachowań i konsekwencjętność sygnatariuszy poszczególnych dokumentów.

\section{ANALIZA WYBRANYCH PRZYKŁADÓW}

Na wstępie zaznaczyć należy, ze rośnie zainteresowanie powyżej zdiagnozowaną formą piętnowania negatywnych zachowań podmiotów - w roku 2007 wpłynęło 121, natomiast w roku 2016 - 707, zaś 2017 r. - 323, zaś w roku 2021 wydano już ponad 100 rozstrzygnięć. Wśród skarżących przeważają osoby fizyczne - konsumenci $^{60}$. Za naganne uznawane są użyte środki perswazyjne, podejmowana tematyka, a także użyte triki - rozwiązania technologiczne.

Postać kobiety w reklamach często ukazywana jest instrumentalnie. Nagość, erotyka, seksapil, postrzeganie kobiety, jako swoistego rodzaju rekwizytu o nienagannej figurze i wyglądzie wpisało się w obraz medialny i przestało, wśród wielu odbiorów stanowić element zaskoczenia czy negacji. Zapewne gdyby można było wyłącznie, w tym kontekście oceniać kampanię firmy DOVE pod hasłem przewodnim „Talk to your daughter before the beauty industry does”1, nie wzbudziłaby społecznej dyskusji. Obraz ukazywany w ciągu 1.19 minut, to zbiór klatek

${ }^{59}$ Zob. Dobrowolny Kodeks Postępowania w Zakresie Reklamy i Promocji Piwa http://www.krrit.gov.pl/Data/Files/_public/pliki/publikacje/analiza2006_08.pdf (dostęp 30.08.2019 r.).

${ }^{60}$ Co nas razi w reklamie? Podsumowanie działalności Komisji Etyki Reklamy w 2017 r.. Aktualności 10 maja 2018 r., https://www.radareklamy.pl/aktualnosci/co-nas-razi-w-reklamie (dostęp 10.09.2019 r.).

${ }^{61}$ https://www.google.com/search?q=firmy+DOVE+pod+hasłem+przewodnim+,,Talk+t o+your+daughter+before+the+beauty+industry+does $\% 2 C \& o q=$ firmy+DOVE+pod+hasłem +p rze (dostęp 20.09,.2019 r.). 
pokazując na wstępie obraz kilkuletniej dziewczynki, a następnie nagości i wysublimowanego piękna, stanowiących swoistego rodzaju drogowskaz perspektywy życiowej, w którym naczelną zasadą jest koncentrowanie uwagi na utrzymaniu dobrego wyglądu zewnętrznego, niezależnie od wieku, stosowanych środków czy wyrzeczeń. Rola matki ograniczona jest do permanentnego uświadamiania dziecka o potrzebie dbałości o wygląd zewnętrzny i to od najmłodszych lat, z pominięciem racjonalnej oceny innych sfer ludzkiego egzystowania i potrzeb.

Troska o dobro dzieci przesądziła o uznaniu reklamy gum „orbit” (producent Mars Polska Sp. z o.o.), ukazującej dziecko przypierające do muru rówieśnika i wypowiadające słowa: "Dawaj kasę!"- jako stanowiącą część kampanii reklamowej realizowanej pod wspólnym hasłem „Czas zabłysnąć”. Mimo argumentacji przytoczonej przez producenta, że reklama adresowana jest do osób powyżej 12 roku życia, a nadto emitowana jest nie przed audycjami adresowanymi do dzieci, to jednak powyższa argumentacja nie zyskała przychylności Zespołu Oceniającego. W uzasadnieniu stwierdzono, że „ (...) nie była prowadzona w poczuciu odpowiedzialności społecznej. Zespół Orzekający dopatrzył się w reklamie treści zagrażających fizycznemu, psychicznemu lub moralnemu dalszemu rozwojowi dzieci lub młodzieży"62.

Zarzut prezentowania treści seksualnych - zdaniem innych pornograficznych - z udziałem chłopca poniżej 15 roku życia podniesiono w stosunku reklamy napoju „Devil Energy Drink” firmy WATERIUS Sp. z o.o. z siedzibą w Jaworze. To kolejna wersja spotu budząca wiele kontrowersji. W roku 2018 Sąd Okręgowy w Legnicy mocą wyroku zakazał emisji reklamy prezentującej wizerunek młodej kobiety z uniesioną twarzą, której podbródek podtrzymuje męska dłoń. W dolnej części obrazu zamieszczono opakowanie napoju Devil i hasło „Ona już wie co za chwilę będzie miała w ustach”. Sąd uznał zasadność pozwu wniesionego przez Stowarzyszenie Twoja Sprawa i nakazał opublikować przeprosiny, wpłacić na poczet fundacji „Dla Polonii” w Warszawie karę 60000.00 zł oraz zakazał rozpowszechnia jej treści. (zob. Ilustracja 1).

Mimo to w kolejnym roku zdecydowano się na rozpowszechnienie kolejnej szokującej reklamy. Ukazana postać dziecka, co najmniej niekompletnie ubranego, dla wielu internatów nagiego z rozchylonymi ustami na tle hasła „Roman już wie co niedługo będzie miał w ustach" spowodowała wiele protestów. (Ilustracja 2)

${ }^{62}$ Uchwała Nr ZO 62/19/37u, z dnia 23 maja 2019 roku, Zespołu Orzekającego, w sprawie sygn. akt:KER/111/19, https://www.radareklamy.pl/uchwaly-ker/2019/uchwa\%C5\%82a-nr-zo-62-19-37u-w-sprawie-reklamy-telewizyjnej-mars-polska. 


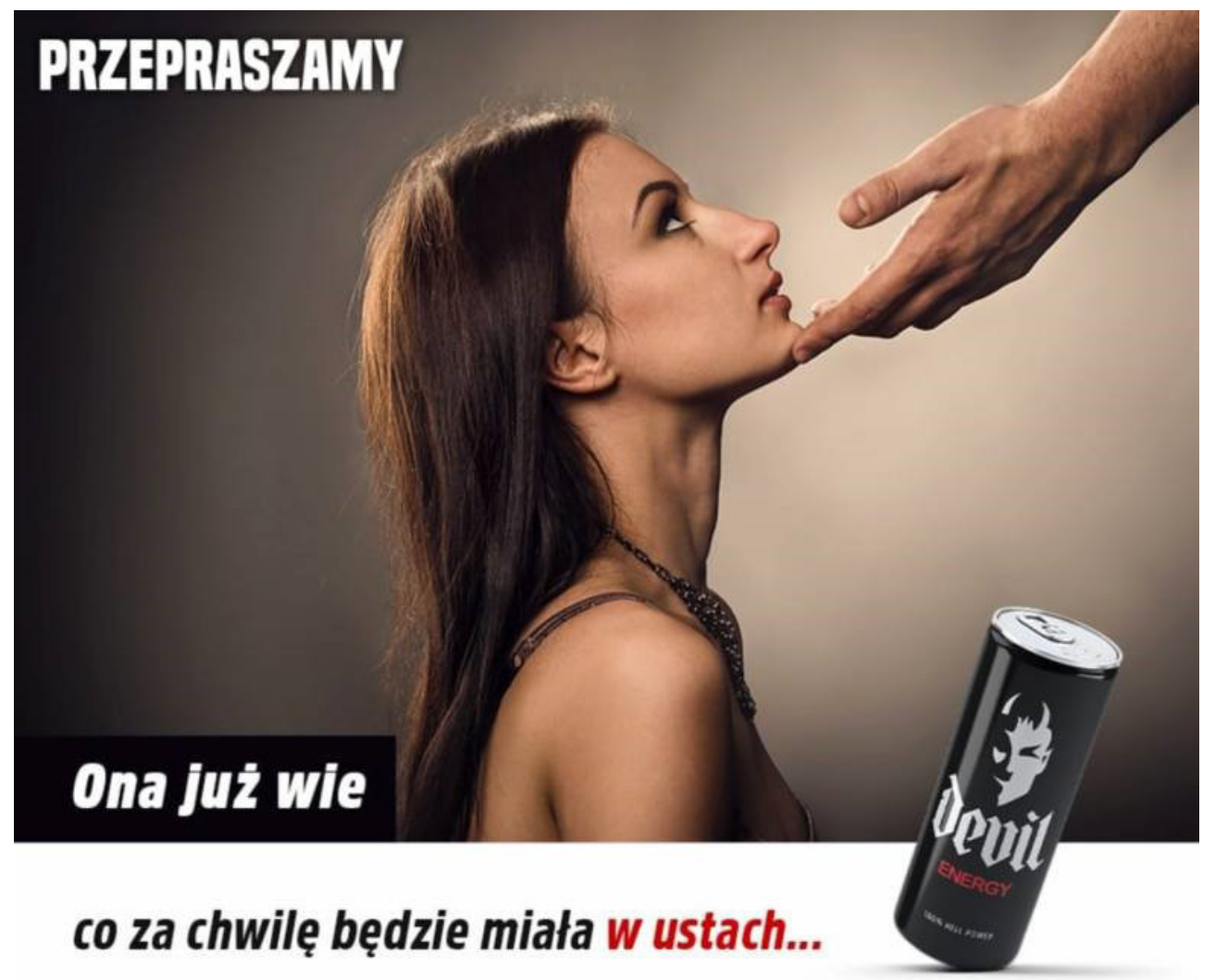

Źródło: Dziennik Zachodni z 23 sierpnia 2018 r, odni.pl/skandaliczna-reklama-devilenergy-drink-ukarana-ona-juz-wie-co-za-chwile-bedzie-miala-w-ustach-firma-wateriusma-przeprosic-i/ga/13434765/zd/30734605

Najczęściej internauci podnosili, że reklama propaguje treści pornograficzne, „(...) unormalnia zjawisko pedofilii. Ofiary tych czynów, które często po wielu latach mają problemy natury psychicznej i trudno jest im się pogodzić z tym co je spotkało, w odbiorze takiej reklamy narażone są m.in. na powrót traumatycznych wspomnień. Może to wywołać u nich stany depresyjne, zespół stresu pourazowego i inne" ${ }^{63}$. Zespół Orzekający Rady Etyki Reklamy przychylił się do podnoszonych zarzutów. Krytycznie oceniono sposób obrazowania tematu związanego z seksualnym

${ }^{63}$ Uchwała Nr ZO 58/19/26o. z dnia 15 maja 2019 roku. Zespołu Orzekającego. w sprawie sygn. akt: KER/61/19/01-78. 


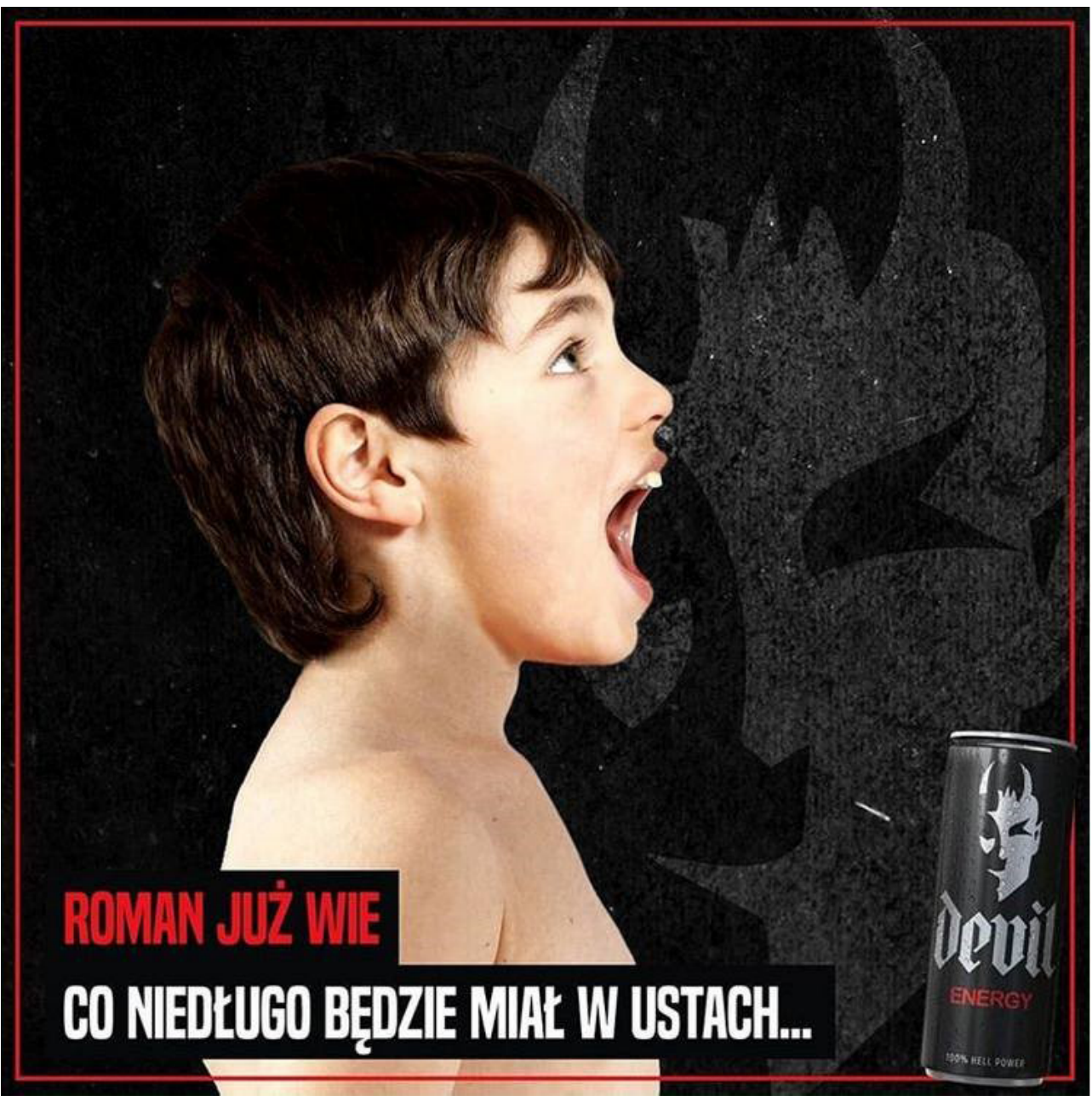

Źródło; Cyt. za Gazeta Krakowsa zdnia 31 stycznia 2019 r; https://gazetakrakowska.pl/ reklama-devil-energy-drink-z-nagim-chlopcem-oburzyla-internautow-roman-juz-wie-coniedlugo-bedzie-mial-w-ustach/ar/138503

wykorzystywaniem dzieci i budowaniem żartobliwej treści, a zatem zarzucono, iż narusza dobre obyczaje, dobry smak i z tego względu nie powinna być rozpowszechniana.

Bywają także skargi, których Komisja nie uwzględnia. Mocą decyzji Komisja Etyki Reklamy, z dnia 31 lipca 2019 roku nie dopatrzyła się błędów i co za tym idzie potwierdzenia zarzutów dotyczących uprzedmiotowienia mężczyzn w reklamie przyprawy marki Maggi/Winiary produkowanej przez firmę Nestle, 
emitowanej w Internecie i telewizji ${ }^{64}$. Podzielono argumentację reklamodawcy, że celem nie było dyskryminowanie mężczyzn, a jedynie żartobliwa, humorystyczna forma ujęcia tematu. „W przedmiotowej reklamie główna bohaterka w odpowiedzi na zapytanie koleżanek „Przywiozłaś coś sobie z tej Kalifornii?” odpowiada jedynie żartobliwie „Przywiozłam” mając na myśli „kogoś” czyli mężczyznę, który pojawia się w reklamie zaraz po wypowiedzeniu przez nią tych słów (nie mówi natomiast w odniesieniu do tegoż mężczyzny, że przywiozła „coś”). Wskazać również należy, że mężczyzna występujący w reklamie jest otaczany w niej uczuciem ze strony głównej bohaterki reklamy i podziwem ze strony jej koleżanek, towarzyszy mu atmosfera adoracji. A sam mężczyzna występujący w reklamie zdaje się być zadowolony z towarzystwa głównej bohaterki i odwzajemniać jej uczucie, tym samym nie może być mowy o przedmiotowym, dyskryminującym czy lekceważącym jego traktowaniu"65. Komisja nie dopatrzyła się naruszenia art. 4 Kodeksu Etyki Reklamy, w myśl którego „Reklamy nie mogą zawierać treści dyskryminujących, w szczególności ze względu na rasę, przekonania religijne, płeć lub narodowość".

\section{ZAKOŃCZENIE}

Postawiona na wstępie hipoteza o tym, że zachodzące procesy samokontroli środowiska reklamodawców odzwierciedlone w przyjętych rozwiązaniach pozanormatywnych, wpisują się w katalog założeń związanych ze społeczną odpowiedzialnością biznesu, ale przede wszystkim wyznaczają granice wolności wypowiedzi gospodarczej sankcjonowane m.in. dobrymi obyczajami i deontologią zawodową - została sfalsyfikowana pozytywnie. Zatem środowisko reklamodawców i dostawców treści hołduje zasadzie społecznej odpowiedzialności biznesu, czego wyrazem są stanowione rozwiązania pozanormatywne oraz skuteczność ich egzekucji przez uprawnione organy. Obecność instytucji stojących

${ }^{64}$ Skargi o sygnaturze akt KER/138/19, KER/139/19 i KER/140/19., https://www.radareklamy.pl/uchwaly-ker/2019/uchwa\%C5\%82a-nr-zo-79-19-48u-w-sprawie-reklamytelewizyjne-nestle-polska.

${ }^{65}$ Uchwała Nr ZO 79/19/48u. z dnia 31 lipca 2019 roku. Zespołu Orzekającego. w sprawie sygn. akt: KER/138/19, KER/139/19 i KER/140/19,https://www.radareklamy. pl/uchwaly-ker/2019/uchwa\%C5\%82a-nr-zo-79-19-48u-w-sprawie-reklamy-telewizyjnenestle-polska. 
na straży przestrzegania etyki na stałe wkomponowała się w system instytucjonalnych rozwiązań krajowych i międzynarodowych. Wydawane rozstrzygnięcia nie tylko są reakcją na to co społecznie budzi wątpliwości, ale ich treści ukazują zmiany zachodzące w polskim społeczeństwie w obszarze kultury, socjologii czy marketingu.

\section{Świadomość skutecznego oddziaływania treści przekazów reklamowych na zachowania i postawy społeczne przyczynia się, nie tylko do rozwoju normatywnych, ale pozanormatywnych rozwiązań reglamentujących wypowiedzi.}

Świadomość skutecznego oddziaływania treści przekazów reklamowych na zachowania i postawy społeczne przyczynia się, nie tylko do rozwoju normatywnych, ale pozanormatywnych rozwiązań reglamentujących wypowiedzi. W ostatnich latach wzrasta zaangażowanie społeczeństwa w dysputę publiczną w kwestiach dotyczących spraw istotnych, w tym także granic wolności wypowiedzi gospodarczej. Uczciwa konkurencja i konkurencyjność nie są jedynymi determinantami piętnowania tego, co społecznie naganne. Odpowiedź na pytanie badawcze dotyczące stopnia w jakim samoregulacja oddziałuje na treść emitowanych reklam okazała się karkołomnym zadaniem, chociaż zauważalny jest wpływ procesów samoregulacyjnych na zawartość reklamową, jednak problematyczne okazało się zbadanie stopnia, czy zakresu tego wpływu. Kwestia stopnia wpływu procesu samoregulacji - pozostaje otwarta i powinna stanowić przedmiot dalszych badań empirycznych ilościowych i jakościowych.

Analiza ram teoretycznych (w tym pojęć podstawowych), jak i ocena działalności funkcjonujących w Polsce organizacji oraz skuteczności wydanych rozstrzygnięć - skłania konkluzji. 0 doniosłości roli wydanych rozstrzygnięć przesądza fakt ich respektowania przez reklamodawców wyrażany m.in. ograniczeniem ich upowszechniania czy weryfikacją treści reklamy. Zbiory decyzji są odzwierciedleniem kultury branżowej, aprobowanego systemu wartości, a także wiedzy dla 
innych zainteresowanych tą formą aktywności gospodarczej podmiotów. W kontekście działalności instytucji marketingowych: zleceniodawców, twórców i dystrybutorów reklam - generują one potrzebę samoregulacji, samowychowywania, samooczyszczania.

Coraz częściej konsumenci korzystają z rozwiązań proceduralnych dla wyrażenia własnego niezadowolenia, ale również poprzez aktywny udział w organizowanych ruchach społecznych czy dystrybuowania opinii i stanowisk w mediach społecznościowych. Tak wysoki poziom zaangażowania z jednej strony stanowi o tym, że reklamy, kampanie są oglądane przez ich adresatów i są skuteczne, z drugiej zaś motywuje osoby odpowiedzialne do prezentowania treści zgodnych zarówno z prawem, jak i etyką. W tym sensie samoregulacja ma fundamentalne znaczenie uzupełniające, $\mathrm{w}$ relacji do norm prawnych. Ponadto możliwość przenoszenia schematów zawartych w scenariuszach spotów reklamowych do życia codziennego, a zwłaszcza wynikające z nich obawy na przyszłość, inspiruje do prowadzenia kontroli społecznej, obywatelskiej.

\section{BIBLIOGRAFIA}

\section{Akty normatywne}

Rozporządzenie Parlamentu Europejskiego i Rady (UE) nr 1169/2011 z dnia 25 października w sprawie przekazywania konsumentom informacji na temat żywności, Dz. Urz. WE. L 304/18 z 22.11.2011.

Rozporządzenie Parlamentu Europejskiego i Rady (WE) nr 1924/2006 z 20 grudnia 2006r. w sprawie oświadczeń żywieniowych i zdrowotnych dotyczących żywności. Dz. Urz. UE z 30 grudnia 2006, L 404/9.

Dyrektywa 2005/29/WE Parlamentu Europejskiego i Rady z dnia 11 maja 2005r. w sprawie nieuczciwych praktyk handlowych stosowanych przez przedsiębiorstwa wobec konsumentów na rynku wewnętrznym oraz zmieniająca dyrektywę Rady 84/450/ EWG, dyrektywy 97/7/WE i 2002/65/WE Parlamentu Europejskiego i Rady oraz rozporządzenie (WE) 2006/2004, Dz. Urz. WE L 149 z 11.06.2005.

Dyrektywa Parlamentu Europejskiego i Rady (UE) 2018/1808 z dnia 14 listopada 2018 r. zmieniająca dyrektywę 2010/13/UE w sprawie koordynacji niektórych przepisów ustawowych, wykonawczych i administracyjnych państw członkowskich dotyczących świadczenia audiowizualnych usług medialnych (dyrektywa o audiowizualnych usługach medialnych) ze względu na zmianę sytuacji na rynku, PE/33/2018/ REV/1, OJ L 303, 28.11.2018, p. 69-92.

Ustawa z dnia 23 kwietnia 1964 r. - Kodeks cywilny, tj. Dz. U. z 2019 r. poz. 1145, 1495. 
Ustawa z dnia 16 kwietnia 1996 r. o zwalczaniu nieuczciwej konkurencji, tj. Dz. U. z 2019 r. poz. 1010 .

\section{Decyzje, uchwały}

Uchwała Nr ZO 62/19/37u, z dnia 23 maja 2019 roku, Zespołu Orzekającego, w sprawie sygn. akt:KER/111/19, https://www.radareklamy.pl/uchwaly-ker/2019/ uchwa\%C5\%82a-nr-zo-62-19-37u-w-sprawie-reklamy-telewizyjnej-mars-polska

Uchwała Nr ZO 58/19/26o. z dnia 15 maja 2019 roku. Zespołu Orzekającego. w sprawie sygn. akt: KER/61/19/01-78.

Uchwała Nr ZO 79/19/48u. z dnia 31 lipca 2019 roku. Zespołu Orzekającego. w sprawie sygn. akt: KER/138/19, KER/139/19 i KER/140/19,https://www.radareklamy. pl/uchwaly-ker/2019/uchwa\%C5\%82a-nr-zo-79-19-48u-w-sprawie-reklamytelewizyjne-nestle-polska

\section{Orzecznictwo}

Wyrok SN z dnia 18 lutego 2016 r., II CSK 282/15, OSNC 2017/1/10.

Wyrok SA w Krakowie z dnia 26 października 2000 r., I ACa 701/00, LEX nr 76680.

Wyrok SA w Warszawie z dnia 4 marca 2013 r., I ACa 923/12, LEX nr 1324807.

\section{Akty pozanormatywne}

Karta etyczna mediów, http://www.dziennikarzerp.pl/wp-content/uploads/2010/06/ karta_dziennikarzy.pdf

Kodeks Etyki Reklamy, Warszawa, 11 września 2019 r., https://www.radareklamy.pl/ pelna-tresc-ker

Regulamin Rozpatrywania Skarg z dnia 19.01.2018 r. ze zm. z dn. 11.05.2018 r. dot. pkt. 24, https://www.radareklamy.pl/images/Dokumenty/RRS_19.01.2018_ze_zm._ 11.05.2018.pdf

Załącznik Nr 3 Karta Ochrony Dzieci w Reklamie, Warszawa, 11 września 2019 r.

\section{Publikacje zwarte}

Barańska M., Polityka ograniczania reklamy w polskiej telewizji. Studium politologiczno prawne, Wydawnictwo WNPiD UAM, Poznań 2012.

Bertrand C.J., Deontologia mediów, przekł. T. Szymański, Instytut Wydawniczy PAX, Warszawa 2007.

Gasparski W., Etyka biznesu - szkice do portretu, w: Dietl J., Gasparski W. (red.), Etyka biznesu, Wydawnictwo Naukowe PWN, Warszawa 1997.

Kraus A., Zoll F., Polska ustawa o zwalczaniu nieuczciwej konkurencji, Poznań 1929.

Płóciennik I., Podlawska D. (red.), Słownik wiedzy o języku, Bielsko-Biała 2004.

Sanecka E., Psychologiczne mechanizmy oddziaływania reklamy a manipulacja $w$ reklamie, Katowice 2012. 
Sroka R. Nieodkryci przywódcy współczesnej etyki biznesu, Poltext, Warszawa 2021.

\section{Artykuły}

Ogrodowczyk A., Żebrowska L., Murawska - Najmiec E., Twardowska K., Samoregulacja i wspótregulacja jako metoda rozwiq̨zywania napięć $w$ relacjach rynek - regulator, Departament Strategii Biura KRRiT, Warszawa 2018.

Piekarczyk A., Kultura etyczna jako podstawowy czynnik kształtujący wysokq jakość zarzqdzania przedsiębiorstwem, „Zeszyty Naukowe Akademii Ekonomicznej w Poznaniu”, Poznań 2007 r., nr 88.

Stępka P., Kołodziejczak W., Mechanizmy samo- $i$ współregulacyjne $w$ obszarze mediów, Analiza Biura KRRiT, Warszawa 2006.

\section{Netografia}

Co nas razi $\mathrm{w}$ reklamie? Podsumowanie działalności Komisji Etyki Reklamy w 2017 r.. Aktualności 10 maja 2018 r., https://www.radareklamy.pl/aktualnosci/ co-nas-razi-w-reklamie

Dziennik Zachodni z dnia 23asierpnia 2018 r, odni.pl/skandaliczna-reklama-devil-energydrink-ukarana-ona-juz-wie-co-za-chwile-bedzie-miala-w-ustach-firma-waterius-maprzeprosic-i/ga/13434765/zd/30734605.

Dzieci lepiej chronione przed reklamami. Standardy przekazów marketingowych mają obowiązywać też w Internecie,https://serwisy.gazetaprawna.pl/media/artykuly /1429756,jak-chronic-dzieci-przed-reklamami.html

Encyklopedia PWN, https://encyklopedia.pwn.pl/haslo/etyka;3898956.html.

Gantner A., Tomaszewska- Pielacha W., Polska Federacja Producentów Żywności Związek Pracodawców, Trzy lata funkcjonowania w Polsce samoregulacji w zakresie reklamy żywności skierowanej do dzieci, https://www.pfpz.pl/trzy-lata-funkcjonowania-wpolsce-samoregulacji-w-zakresie-reklamy-zywnosci-skierowanej-do-dzieci-15406

Gazeta Krakowka z dnia 31 stycznia 2019 r,; https://gazetakrakowska.pl/reklama-devilenergy-drink-z-nagim-chlopcem-oburzyla-internautow-roman-juz-wie-co-niedlugobedzie-mial-w-ustach/ar/138503

Słownik Języka Polskiego, https://sjp.pwn.pl/slowniki/kodeks.html

\section{Biogram}

Dr hab. prof. UJ Marzena Barańska, Pracownik Wydział Zarządzania i Komunikacji Społecznej, Instytut Kultury. Zainteresowania badawcze dotyczą: aspektów prawnych marketingu, zwłaszcza reklamy, product placament, sponsoringu, przekazu medialnego, ochrony praw najmłodszych odbiorców, ochrony konsumenta, reglamentacji rynku farmaceutycznego i aptecznego, a także kontroli rynku reklamy przez uprawnione organy i instytucje.

ORCID: 0000-0003-0026-9803 
Dr hab. Prof. UWr. Lucyna Szot, pracownik Uniwersytetu Wrocławskiego Wydziału Nauk Społecznych, Instytut Politologii. Zainteresowania badawcze dotyczą: systemów medialnych, komunikowania politycznego, studiów nad dziennikarstwem, prawa mediów, prawa reklamy, prawa pracy, zarządzania informacją i treścią reklamową, ochroną własności intelektualnej.

ORCID: 0000-0001-5045-3276 